\title{
Multiple environmental factors influence 238U, 232Th and 226Ra bioaccumulation in arbuscular mycorrhizal- associated plants
}

DOI:

10.1016/j.scitotenv.2018.05.370

\section{Document Version}

Accepted author manuscript

Link to publication record in Manchester Research Explorer

Citation for published version (APA):

Davies, H., Rosas Moreno, J., Cox, F., Lythgoe, P., Bewsher, A., Livens, F., Robinson, C. H., \& Pittman, J. (2018). Multiple environmental factors influence 238U, 232Th and 226Ra bioaccumulation in arbuscular mycorrhizalassociated plants. Science of the Total Environment, 640-641, 921-934.

https://doi.org/10.1016/j.scitotenv.2018.05.370

Published in:

Science of the Total Environment

\section{Citing this paper}

Please note that where the full-text provided on Manchester Research Explorer is the Author Accepted Manuscript or Proof version this may differ from the final Published version. If citing, it is advised that you check and use the publisher's definitive version.

\section{General rights}

Copyright and moral rights for the publications made accessible in the Research Explorer are retained by the authors and/or other copyright owners and it is a condition of accessing publications that users recognise and abide by the legal requirements associated with these rights.

\section{Takedown policy}

If you believe that this document breaches copyright please refer to the University of Manchester's Takedown Procedures [http://man.ac.uk/04Y6Bo] or contact uml.scholarlycommunications@manchester.ac.uk providing relevant details, so we can investigate your claim.

\section{OPEN ACCESS}


1 Multiple environmental factors influence ${ }^{238} \mathrm{U},{ }^{232} \mathrm{Th}$ and ${ }^{226} \mathrm{Ra}$ bioaccumulation

2 in arbuscular mycorrhizal-associated plants

3

4 Helena S. Davies ${ }^{a}$, Jeanette Rosas-Moreno ${ }^{a}$, Filipa Cox ${ }^{a}$, Paul Lythgoe $^{a}$, Alastair Bewsher ${ }^{a}$,

5 Francis R. Livens ${ }^{\mathrm{a}, \mathrm{b}}$, Clare H. Robinson ${ }^{\mathrm{a}, \star}$, and Jon K. Pittman ${ }^{\mathrm{a}, \star}$

6

7 aschool of Earth and Environmental Sciences, The University of Manchester, Oxford Road,

8 Manchester, M13 9PL, UK; ${ }^{b}$ Centre for Radiochemistry Research, School of Chemistry, The

9 University of Manchester, Oxford Road, Manchester, M13 9PL, UK

10

$11{ }^{*}$ Corresponding author.

12 Email address: jon.pittman@manchester.ac.uk (J.K. Pittman)

13 Email address: clare.robinson@manchester.ac.uk (C.H. Robinson)

14

15

16 
Ecological consequences of low-dose radioactivity from natural sources or radioactive waste are important to understand but knowledge gaps still remain. In particular, the soil transfer and bioaccumulation of radionuclides into plant roots is poorly studied. Furthermore, better knowledge of arbuscular mycorrhizal (AM) fungi association may help understand the complexities of radionuclide bioaccumulation within the rhizosphere. Plant bioaccumulation of uranium, thorium and radium was demonstrated at two field sites, where plant tissue concentrations reached up to $46.93 \mu \mathrm{g} \mathrm{g}^{-1238} \mathrm{U}, 0.67 \mu \mathrm{g} \mathrm{g}^{-1}{ }^{232} \mathrm{Th}$ and $18.27 \mathrm{kBq} \mathrm{kg}^{-1}{ }^{226} \mathrm{Ra}$. High root retention of uranium was consistent in all plant species studied. In contrast, most plants showed greater bioaccumulation of thorium and radium into above-ground tissues. The influence of specific soil parameters on root radionuclide bioaccumulation was examined. Total organic carbon significantly explained the variation in root uranium concentration, while other soil factors including copper concentration, magnesium concentration and $\mathrm{pH}$ significantly correlated with root concentrations of uranium, radium and thorium, respectively. All four orders of Glomeromycota were associated with root samples from both sites and all plant species studied showed varying association with AM fungi, ranging from zero to $>60 \%$ root colonization by fungal arbuscules. Previous laboratory studies using single plant-fungal species association had found a positive role of AM fungi in root uranium transfer, but no significant correlation between the amount of fungal infection and root uranium content in the field samples was found here. However, there was a significant negative correlation between AM fungal infection and radium accumulation. This study is the first to examine the role of AM fungi in radionuclide soil-plant transfer at a community level within the natural environment. We conclude that biotic factors alongside various abiotic factors influence the soil-plant transfer of radionuclides and future mechanistic studies are needed to explain these interactions in more detail.

Keywords: Arbuscular mycorrhizal fungi; Environmental radioactivity; Plants; Radium; 


\section{Introduction}

Radionuclides, such as ${ }^{238} \mathrm{U},{ }^{232} \mathrm{Th}$ and ${ }^{226} \mathrm{Ra}$, are concentrated above background levels in environments with naturally occurring radioactive materials (NORM) because of the underlying geological characteristics, and concentrations may be further enhanced by activities such as mining and processing of radioactive ore. High concentrations of ${ }^{238} \mathrm{U}$, ${ }^{232} \mathrm{Th}$ and ${ }^{226} \mathrm{Ra}$ can be a potential risk to ecosystem health because of radioactivity and chemotoxic effects when accumulated at high concentrations within biological tissues (Davies et al., 2015; IAEA, 1994; Saenen et al., 2013). As such, understanding the behaviour, mobility and transfer of radionuclides is critical for the development of management strategies for contaminated sites, and is relevant to NORM contamination, nuclear site clean-up and disposal of radioactive waste. Uranium is of particular research interest because of its abundance, its presence at former mining and ore processing sites (Malin and Petrzelka, 2010; Winde et al., 2017), and also because of the dependency of its environmental mobility on chemical oxidation state (IAEA, 1994; Mitchell et al., 2013). around the world, and have mostly examined radionuclide uptake into agricultural plants, including the transfer of ${ }^{238} \mathrm{U},{ }^{232} \mathrm{Th}$ and ${ }^{226} \mathrm{Ra}$ into watermelon and zucchini (Al-Kharouf et al., 2008) or wheat plants (Pulhani et al., 2005), and the accumulation of ${ }^{226} \mathrm{Ra}$ into various leafy vegetables and fruits (Ross et al., 2013) and into rice plants (Karunakara et al., 2013). In all of these examples detectable but often very low concentrations of radionuclides have been observed in edible tissues. Such studies have typically quantified transfer factors (TFs), which are the ratio between radionuclide concentration in the plant to that in soil (IAEA, 2009; Mitchell et al., 2013), to indicate bioaccumulation and support risk estimates. However, relatively few studies have focussed on the non-crop plant species that are native to NORM and technologically enhanced NORM environments. Furthermore, most analyses have only quantified radionuclide bioaccumulation into above-ground plant tissues (Vera Tomé et al., 2003; Vera Tomé et al., 2002) without a detailed analysis of root and 
rhizosphere characteristics. This gives an inaccurate picture of the role of plants in radionuclide transfer, especially as roots are essential for the transfer of elements such as ${ }^{238} \mathrm{U},{ }^{232} \mathrm{Th}$ and ${ }^{226} \mathrm{Ra}$ into above-ground tissues, while there is also substantial evidence of the retention of radionuclides in roots; for example, preferential accumulation of uranium was observed in hydroponically grown tobacco plants (Soudek et al., 2014) and soil grown wheat plants showed $75 \%, 57 \%$ and $54 \%$ distribution within root tissue of ${ }^{238} \mathrm{U},{ }^{232} \mathrm{Th}$ and ${ }^{226} \mathrm{Ra}$, respectively (Pulhani et al., 2005). A more complete understanding of radionuclide partitioning would be useful for determining whether there are greater risks for radionuclide food chain transfer via above-ground vegetation herbivores or via soil microorganisms and animals who feed on roots.

Arbuscular mycorrhizal (AM) fungi are associated with $80-90 \%$ of terrestrial plant species (Harrison, 1997) and provide a vital interface between the soil and plants. AM fungi extend beyond the rhizosphere and contribute significantly to essential element and nutrient uptake from the soil into the roots, in exchange for carbon assimilated by the host plant (Harrison, 1997; Harrison et al., 2002). Evidence from laboratory-based studies that have examined single plant-single fungus species associations has shown that AM fungal hyphae can access and transport ${ }^{238} \mathrm{U}$ from source to root sinks, while root retention of ${ }^{238} \mathrm{U}$ was greater when plants were mycorrhizal, as seen in Medicago plants (Chen et al., 2005a), barley (Chen et al., 2005b), and carrot roots (Rufyikiri et al., 2003). However, no previous radioecology study has included data regarding AM fungi within the natural environment or considered the mycorrhizal status of the plants at a radionuclide contaminated field site.

Therefore to identify biotic factors in addition to abiotic factors that may influence radionuclide transfer in these ecosystems this present study was undertaken with the objective to determine the tissue-specific partitioning of ${ }^{238} \mathrm{U},{ }^{232} \mathrm{Th}$ and ${ }^{226} \mathrm{Ra}$ in natural field site plants and secondly to examine the influence of AM fungi association on radionuclide accumulation into these plant tissues. In particular, we aimed to test the hypothesis that AM fungi can enhance the transfer of radionuclides from soil to plants within the field. 
We present data describing the partitioning of ${ }^{238} \mathrm{U},{ }^{232} \mathrm{Th}$ and ${ }^{226} \mathrm{Ra}$ between plant

roots and shoots, together with soil-to-plant TFs of these radionuclides from plants at both sites that show AM fungi association. As well as determining soil chemistry, we performed multivariate analyses and correlations between root concentrations of ${ }^{238} \mathrm{U},{ }^{232} \mathrm{Th}$ and ${ }^{226} \mathrm{Ra}$ with soil abiotic parameters and AM fungal infection parameters in order to identify key influencing factors. This has allowed the generation of a more comprehensive dataset, which considers a broader ecological viewpoint of radionuclide-impacted natural environments.

\section{Material and methods}

\subsection{Field sampling}

This study used two 'natural laboratory' field sites within the UK, at South Terras in Cornwall and Needle's Eye in Scotland (Fig. 1). Elevated concentrations of ${ }^{238} \mathrm{U}$ and ${ }^{226} \mathrm{Ra}$ are present at South Terras because of historic uranium mining, which occurred on site until the early 1900's (Siddeeg et al., 2015). Secondary uranium ores torbernite and autunite have been identified at South Terras, with organic soils overlaying many of the remaining mine spoil heaps, which in turn sit astride predominantly gravel, sand and silt layers (Corkhill et al., 2017; Purvis et al., 2004; Read et al., 1991). Read et al. (1991) should be referred to for a detailed description of the geochemistry and hydrogeology of South Terras. In contrast, at Needle's Eye, several urananite, pitchblende veins are exposed at the local cliff face with an anoxic bog zone of highly organic soil, immediately south of the exposed cliff face (Basham et al., 1991; MacKenzie et al., 1991). The local geology at Needle's Eye comprises of granodiorite/felsite, silurian hornfelsted and carboniferous sediments and is described in greater detail by Basham et al. (1991). Field sampling was performed at South Terras and Needle's Eye in late spring (May) 2014. During 2014 annual precipitation at South Terras was $1232.5 \mathrm{~mm}$ (102.7 mm mean monthly; $75.4 \mathrm{~mm}$ during sample month) and mean temperature was $9.0^{\circ} \mathrm{C}$ (minimum) $-14.3^{\circ} \mathrm{C}$ (maximum), while annual precipitation at Needle's Eye was 1263.3 mm (105.3 mm mean monthly; 112 mm during sample month) and 
mean temperature was $5.7^{\circ} \mathrm{C}$ (minimum) $-13.3^{\circ} \mathrm{C}$ (maximum). Sampling at South Terras was carried out at two areas in late May 2014 (Fig. 1a). Sampling at Needle's Eye took place in early May 2014 and extended from the uraninite source at the cliff face to the area below the cliff face, with most samples taken from this uranium-rich bog area (Fig. 1b). Plant samples were chosen on the basis of dominance across each field site, consequently it was not possible to collect the same plant species from each site. Figure 1 lists the plant species collected and included Asplenium scolopendrium L. $(\mathrm{n}=2)$ and Primula vulgaris Huds. $(\mathrm{n}=$ 4) from South Terras, and Chrysosplenium oppositifolium L. $(\mathrm{n}=3)$, Iris pseudacorus $\mathrm{L}$. $(\mathrm{n}=$ 3) and Oenanthe crocata L. $(n=3)$ from Needle's Eye (as identified by DNA analysis detailed in section 2.4 and 3.1). Where possible, three or four plant samples were collected for each species although only two samples of $A$. scolopendrium were collected. Each plant sample was labelled with a site number (S1 - S5 for South Terras; N1 - N9 for Needle's Eye) (Fig. 1), giving a total of six collected plant samples from South Terras and nine from Needle's Eye. Whole plant specimens were removed with soil surrounding the roots and the root system left undisturbed, thus there were identical numbers of soil samples as plant samples from South Terras and Needle's Eye for geochemical analysis.

\subsection{Soil sample processing and analysis}

Soil was carefully removed from the roots of each plant and separated into aliquots for analysis. Large stones or detritus were removed and soil was dried in a $40{ }^{\circ} \mathrm{C}$ incubator for 48 h. Soil pH was determined as described previously (Allen, 1974; Krause, 1978). Dried soil samples were ground by pestle and mortar then $0.1 \mathrm{mg}$ samples were furnace heated at $900^{\circ} \mathrm{C}$ (for total carbon), or furnace heated at $500^{\circ} \mathrm{C}$ after phosphoric acid addition (for total inorganic carbon (TIC)) then emitted $\mathrm{CO}_{2}$ was detected by a non-dispersive infra-red gas analyser (Shimadzu SSM-5000A, Shimadzu, Milton Keynes, UK). TIC was then subtracted from total carbon to give total organic carbon (TOC) values. For anion quantification, $1 \mathrm{~g}$ samples of powdered soil were mixed and shaken in $10 \mathrm{~mL}$ MilliQ deionised $\mathrm{H}_{2} \mathrm{O}$ then ultrasonicated for $10 \mathrm{~min}$, before supernatant was removed and filtered through a $0.45 \mu \mathrm{m}$ 
156 Millipore MCE membrane. Concentrations of $\mathrm{PO}_{4}{ }^{3-}, \mathrm{NO}_{3}{ }^{-}$and $\mathrm{SO}_{4}{ }^{2-}$ were determined using

157 an ICS-5000 Dual Channel Ion Chromatograph with AG18 Guard Column $(50 \times 2 \mathrm{~mm})$ and

158 Dionex AS18 Analytical Column $(250 \times 2 \mathrm{~mm})$ and conductivity detector (ThermoFisher

159 Scientific, Altrincham, UK). The mobile phase (eluent) was produced using a Dionex

160 Potassium Hydroxide Eluent Generator Cartridge (ThermoFisher Scientific, Altrincham, UK).

161 This is electronically controlled and mixes the KOH with HPLC grade water to produce the desired concentration of eluent. This is pumped at a flow rate of $0.25 \mathrm{~mL} \mathrm{~min}^{-1}$ through the columns. For $\mathrm{NH}_{4}{ }^{+}$quantification, $200 \mu \mathrm{L}$ of Nessler's Reagent (Krug et al., 1979) was mixed with $800 \mu \mathrm{L}$ of the filtered soil supernatant, incubated for $5 \mathrm{~min}$ and measured by absorbance at $420 \mathrm{~nm}$ using an $\mathrm{NH}_{4} \mathrm{Cl}$ standard curve for calibration.

\subsection{AM fungal colonization quantification}

Root samples were collected after the removal of the soil, were rinsed in HPLC grade water four times to further remove soil then stored in $70 \%$ ethanol until staining. Root samples were cleared, rinsed, bleached and acidified as described previously (Koske and Gemma, 1989), then immediately stained and de-stained as described (Newsham and Bridge, 2010). The quantification of AM fungal colonisation was based on an intersection method to rank the presence or absence of fungal structures (McGonigle et al., 1990). De-stained roots were cut into $1 \mathrm{~cm}$ segments, laid horizontal and in parallel on a glass slide and viewed under $100 \mathrm{X}$ magnification with an eyepiece graticule marked with a vertical transect line. The transect line (perpendicular to the root) was placed at the left end of a root section. A fungal structure was recorded as present if the transect line ran through one or several AM fungal structures or as absent if no fungal structure was present (an empty root cell), then the root was moved one field of view to the left and the next transect line outcome was observed. Wherever possible, over 100 intersections per root sample with three biological replicates were recorded except where there was limited available root material (Table S1). Percentage abundance $=\left(\sum \mathrm{A}\right.$ or $\mathrm{V}$ or $\mathrm{H} / \sum$ intersections $) \times 100$, where $\mathrm{A}$ is arbuscule, $\mathrm{V}$ is vesicle and $\mathrm{H}$ is hyphae, and where $\mathrm{H}$ is calculated as the total number of intersections 
minus the negative tally. Micrographs were taken using a Zeiss Imager A.1 microscope with an Axio cam 506mono camera (Zeiss, Jena, Germany).

\subsection{Plant species identification by DNA sequencing}

DNA was extracted from three replicates of leaf tissue per plant sample as described previously (Lodhi et al., 1994), purified by phenol-chloroform-isoamyalcohol extraction and isopropanol precipitation then resuspended in MilliQ $\mathrm{H}_{2} \mathrm{O}$. The flowering plant DNA barcode regions of $r b c L$ and matK were used to identify unknown samples to species level. matK was only amplified when rbcL sequences failed to discriminate to species level. The PCR protocol and primer combinations (Table S2) were as described previously (de Vere et al., 2012). PCR amplified and purified $r b c L$ and matK bands were sequenced (GATC Biotech, Konstanz, Germany) and analysed by BLAST against the Genbank database (Table S3).

\subsection{Fungal species identification by DNA sequencing}

Total DNA was extracted from $\sim 40 \mathrm{mg}$ of frozen plant root tissue using PowerPlant Pro DNA Isolation Kit (MoBio Laboratories, Qiagen Ltd, Manchester, UK). Amplicons for Illumina HiSeq paired-end sequencing were generated from triplicate PCR reactions using 5.8S-Fun and ITS4-Fun primers (Taylor et al., 2016), modified with Nextera overhang adapters (Table S2) to allow addition of sequencing adapters and sample-specific indices in a subsequent PCR. The Nextera forward adapter was added to the ITS4-Fun primer to allow reverse sequencing across the ITS2 region. Triplicate PCR reactions were performed using Phusion HF Master Mix (New England Biolabs Ltd, Hitchin, UK) and PCR amplification conditions of $98^{\circ} \mathrm{C}$ for $30 \mathrm{~s}$, then 28 cycles of $98^{\circ} \mathrm{C}$ for $10 \mathrm{~s}, 55^{\circ} \mathrm{C}$ for $30 \mathrm{~s}, 72^{\circ} \mathrm{C}$ for $30 \mathrm{~s}$; then $72^{\circ} \mathrm{C}$ for 7 min. The triplicate PCR products were pooled and submitted to the Centre for Genomic Research, University of Liverpool, UK, for downstream sample processing and sequencing using an Illumina HiSeq 2500 (Illumina, Cambridge, UK). QIIME 1.9.1 was used for sequence processing (Caporaso et al., 2010). Forward and reverse reads were matched 
with a minimum of $50 \mathrm{bp}$ overlap before filtering to remove short $(<200 \mathrm{bp})$ or low quality reads (minimum average quality score $<25$ ). Chimeric sequences were removed using UCHIME (Edgar et al., 2011). Remaining sequences were grouped into operational taxonomic units (OTUs) at 97\% sequence similarity using USEARCH 6.1 in order to approximate species-level groupings across the fungal kingdom (Edgar, 2010). Single sequence OTUs were removed, and taxonomy was assigned to OTUs in QIIME, by running the BLAST algorithm (maximum E value, 0.001) against the UNITE fungal database (http://www2.dpes.gu.se/project/unite/index.htm) accessed on 20 November 2016.

\section{6. ${ }^{226}$ Ra detection by $y$-spectroscopy}

Plant samples were dried to a constant mass over 3 months at room temperature in a plant press. Dried leaf, stem/petiole, and root tissue was separately homogenized using a KRUPS F203 Moulin grinder (Krups, Solingen, Germany). Homogenized plant tissue ( $n=1$ per tissue type, per individual plant sample), ranging from $0.1-1.5 \mathrm{~g}$ dry weight, or dried ground $1.5 \mathrm{~g}$ soil samples ( $\mathrm{n}=2-4$ per plant species), was added to $125 \mathrm{~mL}$, screw-cap containers. These were placed into $150 \mathrm{~mL}$ containers and the screw cap lid was glued with epoxy resin glue and sealed with parafilm to prevent escape of ${ }^{222} \mathrm{Rn}$, then left for 30 days to ensure that secular equilibrium was reached. The ${ }^{214} \mathrm{Bi}$ and ${ }^{214} \mathrm{~Pb}$ decay product emissions were used to quantify ${ }^{226} \mathrm{Ra}$ activity. Each sample was run on a GEM-S7025-LB-C Ortec Profile S-series HPGe detector (20\% relative efficiency) with a DSPEC-50 Digital signal processor and Gammavision software (Ametek Ortec, Wokingham, UK) for $24 \mathrm{~h}$ (for plant samples) and $6 \mathrm{~h}$ (for soil samples), to record the net areas of ${ }^{214} \mathrm{Bi}$ and ${ }^{214} \mathrm{~Pb}$ peaks at 609.5 $\mathrm{keV}$ and $352.0 \mathrm{keV}$, respectively. A blank was run containing no material. Following completion, three plant tissue samples and two soil samples with the lowest cps values were chosen for preparation of ${ }^{226} \mathrm{Ra}$ - spiked standards. Plant samples were covered with MilliQ $\mathrm{H}_{2} \mathrm{O}$ while soil samples were covered with ethanol, then $100 \mu \mathrm{L}$ of $1 \mathrm{kBq} \mathrm{mL}{ }^{-1}{ }^{226} \mathrm{Ra}$ spike (from a certified standard solution supplied by AEA Technology, Harwell, UK) was added to each container before being left without lids in a sand bath at $80^{\circ} \mathrm{C}$ until all liquid had 
evaporated and the samples were dry. After 30 days re-sealed, the spiked standards were run as before. Plant and soil ${ }^{226} \mathrm{Ra}$ activity concentrations \pm counting error were calculated using equations described in Supplementary Methods (Supplementary Information), based on those described previously (Chen et al., 2005c; IAEA, 1989). Plant sample activity concentrations were adjusted by a Ti correction factor $\left(\mathrm{Ti}_{\%}\right)$ to account for any remnant soil left on the plant tissue (Cook et al., 2009). All plant tissue samples from all species gave average $\mathrm{Ti}_{\%}<6.8 \%$ and average $\mathrm{Ti}$ concentrations $<4.7 \mu \mathrm{g} \mathrm{g}^{-1}$, aside from the $C$. oppositifolium tissue samples, which had an average $\mathrm{Ti}_{\%}$ of $36.1 \%$ and concentration of $10.24 \mathrm{\mu g} \mathrm{g}^{-1}$. This was likely to be partly due to the small mass of $C$. oppositifolium tissue samples.

\subsection{ICP-MS and ICP-AES analyses}

Dried and ground plant tissue $(\sim 0.05-0.1 \mathrm{~g}$ dry weight $)$ and soil samples $(0.1 \mathrm{~g})$ were placed in acid-washed borosilicate boiling tubes, and incubated in $5 \mathrm{~mL}$ (or $0.5 \mathrm{~mL}$ for $\leq 0.05$ g samples) of $70 \%$ ultrapure grade nitric acid at $140{ }^{\circ} \mathrm{C}$ for $3 \mathrm{~h}$. For homogenised plant tissue, $n=3$ per individual plant sample ( $n=1$ leaf, $n=1$ stem/petiole and $n=1$ root) and for soil, $n=3$ per sub-site (such that $n=6-12$ per plant species). Cooled samples were diluted by addition of MilliQ $\mathrm{H}_{2} \mathrm{O}$ to a final volume of $10 \mathrm{~mL}$ (or $2.5 \mathrm{~mL}$ for $\leq 0.05 \mathrm{~g}$ samples) then filtered through a $0.45 \mu \mathrm{m}$ Millipore MCE membrane before a final dilution with MilliQ $\mathrm{H}_{2} \mathrm{O}$ to $10 \mathrm{~mL}$. All soil samples were filtered and diluted (1 in 10) a second time. ICP-MS was performed to quantify ${ }^{238} \mathrm{U}$ and ${ }^{232} \mathrm{Th}$, plus $\mathrm{As}, \mathrm{Pb}, \mathrm{Sn}$ and Ti using an Agilent $7700 \mathrm{x}$ fitted with a collision cell, pressurised with $\mathrm{He}$ at a flow rate of $4.5 \mathrm{~mL} \mathrm{~min}{ }^{-1}$ (Agilent, Stockport, UK). ICP-AES was performed to quantify $\mathrm{Ca}, \mathrm{K}, \mathrm{Mg}, \mathrm{P}, \mathrm{S}, \mathrm{Cu}, \mathrm{Fe}, \mathrm{Mn}$ and $\mathrm{Zn}$ using a Perkin-Elmer Optima 5300 (Perkin-Elmer, Llantrisant, UK). Certified Reference Standard TM25.5 was used for all ICP analyses. All samples were calibrated using a matrix-matched serial dilution of Specpure multi-element plasma standard solution 4 (Alfa Aesar, Heysham, UK) set by linear regression, and only results with a relative standard deviation $<20 \%$ were considered. Plant root sample element concentrations were also adjusted by a $\mathrm{Ti}_{\%}$ to 
account for any remnant soil left on the plant tissue. ICP detection limits for plant tissue analyses were: As $<0.132 \mu \mathrm{g} \mathrm{L}^{-1} ; \mathrm{Ca}<0.004 \mathrm{mg} \mathrm{L}^{-1} ; \mathrm{Cu}<0.029 \mu \mathrm{g} \mathrm{L}^{-1} ; \mathrm{Fe}<0.002 \mathrm{mg} \mathrm{L}^{-1}$; $\mathrm{K}<0.004 \mathrm{mg} \mathrm{L}^{-1} ; \mathrm{Mg}<0.007 \mathrm{mg} \mathrm{L}^{-1} ; \mathrm{Mn}<0.007 \mathrm{mg} \mathrm{L}^{-1} ; \mathrm{P}<0.009 \mathrm{mg} \mathrm{L}^{-1} ; \mathrm{S}<0.017 \mathrm{mg} \mathrm{L}^{-1} ;$ $\mathrm{Sn}<0.021 \mu \mathrm{g} \mathrm{L}^{-1} ; \mathrm{Th}<0.030 \mu \mathrm{g} \mathrm{L}^{-1} ; \mathrm{Ti}<0.263 \mu \mathrm{g} \mathrm{L}^{-1} ; \mathrm{U}<0.002 \mu \mathrm{g} \mathrm{L}^{-1}$ and $\mathrm{Zn}<0.096 \mu \mathrm{g}$ ${ }^{1}$. The detection limits for soil sample analyses by ICP were $<0.000 \mu \mathrm{L} \mathrm{L}^{-1}$ for $\mathrm{As}, \mathrm{Cu}, \mathrm{Sn}$, Th, Ti, $\mathrm{U}$ and $\mathrm{Zn}$ and $\mathrm{Ca}<0.005 \mathrm{mg} \mathrm{L}^{-1} ; \mathrm{Fe}<0.029 \mathrm{mg} \mathrm{L}^{-1}, \mathrm{~K}<0.006 \mathrm{mg} \mathrm{L}^{-1} ; \mathrm{Mg}<0.007$ $\mathrm{mg} \mathrm{L}^{-1} ; \mathrm{Mn}<0.006 \mathrm{mg} \mathrm{L}^{-1} ; \mathrm{P}<0.011 \mathrm{mg} \mathrm{L}^{-1}$ and $\mathrm{S}<0.013 \mathrm{mg} \mathrm{L}^{-1}$.

\subsection{Statistical analyses}

PRIMER v6 was used to perform principal component analysis (PCA). For this analysis a matrix of $9-11$ samples with 24 variables was used. In all cases the distribution of eigenvalue variation across $\mathrm{PC}$ demonstrated that this sample-to-variable ratio was found to be sufficient for PC consistency (Jung and Marron, 2009). Moreover, all data interpretation derived from PCA was further evaluated by linear regression. All data (except for $\mathrm{pH}, \mathrm{TOC}$ and TIC values) were natural log transformed for PCA and subsequent linear regression correlation figures, except for linear regression of ${ }^{232}$ Th data, which was square root transformed. Other statistical analyses were performed using GraphPad PRISM. Unpaired, non-parametric, Mann-Whitney t-tests or unpaired t-tests, with Welch's corrections, were used to test for significant differences between South Terras and Needle's Eye soil characteristics $(P<0.05)$ and soil element (including radionuclide) concentration data $(P<$ 0.05). However, One-Way ANOVA, Kruskall-Wallis, non-parametric tests were used for soil concentration outliers $(P<0.05)$, whilst Two-Way ANOVA analyses, with Tukey's multiple comparisons, was used to test for significant element concentrations (including radionuclides) or TF differences between plant leaf, stem/petiole and root tissue $(P<0.05)$. 


\subsection{Soil characteristics and sampled plant species identification at South Terras and}

The soil at South Terras was significantly more acidic ( $\mathrm{pH} 4.5$ to 5.6) than at Needle's Eye (pH 5.2 to 6.4 ; Fig. 2a). The amounts of TOC were notably different: $39 \pm 5 \%$ at Needle's Eye and $12 \pm 11 \%$ at South Terras (Fig. 2b). Only one South Terras sample had TOC $>30 \%$. In contrast, TIC was very low at all sites, in the range $0.01-0.02 \%$. Concentrations of $\mathrm{PO}_{4}{ }^{3-}$, $\mathrm{NO}_{3}{ }^{-}, \mathrm{SO}_{4}{ }^{2-}$ and $\mathrm{NH}_{4}{ }^{+}$varied between individual sub-sites across both field sites, but there was no significant difference in mean values of $\mathrm{PO}_{4}{ }^{3-}, \mathrm{NO}_{3}{ }^{-}$and $\mathrm{NH}_{4}{ }^{+}$between Needle's Eye and South Terras, however, there was greater variation in soil $\mathrm{PO}_{4}{ }^{3-}$ concentration at Needle's Eye due to one sample of $596 \mu \mathrm{g} \mathrm{g}^{-1} \mathrm{PO}_{4}{ }^{3-}$ compared with a mean value of $114 \mu \mathrm{g}$ $\mathrm{g}^{-1}$ (Fig. 2c-e). South Terras soils had significantly lower concentrations of $\mathrm{SO}_{4}{ }^{2-}$, all $<160 \mu \mathrm{g}$ $\mathrm{g}^{-1}$, whilst the mean $\mathrm{SO}_{4}{ }^{2-}$ concentration was $390 \mu \mathrm{g} \mathrm{g}^{-1}$ at Needle's Eye (Fig. 2f). Mean ${ }^{238} \mathrm{U}$ concentrations were slightly lower at South Terras compared with Needle's Eye where most sample sites had soil ${ }^{238} \mathrm{U}$ concentrations $>200 \mu \mathrm{g} \mathrm{g}^{-1}$. Soil from Needle's Eye at site N1, which was closer to the cliff and outside of the anoxic bog, was a clear outlier $(P=0.0064)$ compared with all other Needle's Eye samples, with much lower ${ }^{238} \mathrm{U}$ concentration. However, there was no significant difference between South Terras and Needle's Eye (Fig. 2g). The concentrations of ${ }^{232}$ Th in soils were generally low in comparison to ${ }^{238} \mathrm{U}$ concentrations. There was also no significant difference between soil ${ }^{232} \mathrm{Th}$ concentrations at both field sites but greater variation at South Terras (Fig. 2h). There was high variation in ${ }^{226} \mathrm{Ra}$ activity within soils collected from South Terras with the greatest activities coming from those sampled from the former ore processing area. The lowest activity was determined from site $\mathrm{S} 1$ at $2 \mathrm{kBq} \mathrm{kg}^{-1}$, whilst an activity of $97 \mathrm{kBq} \mathrm{kg}^{-1}$ was detected at site S2. Such high ${ }^{226} \mathrm{Ra}$ activities were not present at Needle's Eye, where 15

$322 \mathrm{kBq} \mathrm{kg}{ }^{-1}$ at site N6 was the highest recorded. However, there was no significant difference between South Terras and Needle's Eye ${ }^{226}$ Ra concentrations (Fig. 2i). 
In addition to radionuclides, other soil elements were quantified (Table S4). Apart

from $\mathrm{K}$ and $\mathrm{P}$, all other macro-elements ( $\mathrm{Ca}, \mathrm{Mg}$ and $\mathrm{S})$ were present at significantly higher concentrations in Needle's Eye soils compared with South Terras soils (Fig. 3a-e). The trace element $\mathrm{Zn}$ was at significantly elevated concentration in Needle's Eye soils compared with South Terras (Fig. 3i). Fe concentrations were variable but were significantly higher at South Terras in contrast to Needle's Eye soils (Fig. 3g), whereas there was no significant difference in soil $\mathrm{Cu}$ or Mn concentrations (Fig. 3f, h). Soil As and Pb concentrations were significantly higher at the former mine site of South Terras compared with Needle's Eye (Fig. 3j, k), but the two locations had no significant difference in Sn (Table S4).

South Terras and Needle's Eye were both heavily vegetated with mature trees and substantial coverage of understory plants. Smaller understory plants were chosen that could be taken from the site intact for subsequent whole-plant analysis (Fig. S1). The species that were dominant at the time of sampling across both field sites were chosen. Taxonomic classification was confirmed by DNA barcoding (Table S3). Samples from South Terras were identified as $A$. scolopendrium (hart's-tongue fern) and $P$. vulgaris (primrose), while $C$. oppositifolium (opposite-leaved golden saxifrage), I. pseudacorus (yellow iris), and $O$. crocata (water dropwort) were dominant at Needle's Eye (Fig. 1). Most of the South Terras species were sampled from the former uranium ore processing area where a layer of dense organic matter was present over a sandy substratum, directly on top of the concrete processing floors. At Needle's Eye, samples were mainly taken from an anoxic bog area, which was known to exhibit significant retardation of ${ }^{238} \mathrm{U}$ in the soil (Basham et al., 1991; MacKenzie et al., 1991).

\subsection{AM fungal associations with South Terras and Needle's Eye plants}

All South Terras and Needle's Eye plant samples were examined for AM fungal association within the roots. Clear evidence of AM fungal association was found for all plant species examined (Fig. 4). Distinctive morphological characteristics of mycorrhizal fungi such as intraradical hyphae, spores and vesicles, in addition to arbuscules were observed, which 
confirmed AM fungal presence, but no obvious presence of saprotrophic or pathogenic fungal associations. Interestingly, P. vulgaris roots had interspersed regions densely packed with fungal structures that appear to be vesicles (Fig. 4b). These were strongly suggested to be AM fungal structures due to the observation of directly associated hyphae. Structures that did not resemble AM fungal structures and were potentially oomycetes were also identified, and were differentiated from $\mathrm{AM}$ fungal vesicles by their lack of $\mathrm{IH}$ connections and/or protrusion outside the root cell. On average $20 \%$ of $P$. vulgaris roots were colonised with AM fungal vesicles, with one of the $P$. vulgaris samples from site $\mathrm{S} 4$ having $46 \%$ colonisation (Fig. 4h). In contrast, samples from Needle's Eye were mostly lacking in vesicles, with no vesicles present in any $C$. oppositifolium or I. pseudacorus, and in just $2 \%$ of $O$. crocata roots. However, arbuscules and penetrating hyphae were observed in almost all plant samples from both field sites, but there was variation in the amount of AM fungal infection between individual samples (Fig. $4 \mathrm{f}, \mathrm{g}$ ).

In order to look at the community composition and validate the presence of AM fungi in South Terras and Needle's Eye samples, sequencing was performed of fungal-specific ribosomal RNA internal transcribed spacer (ITS) region amplicon libraries generated from root DNA samples. A total of 2,728 non-singleton OTUs, from a total of $6,402,166$ sequences, were identified from all samples. After removal of non-fungal OTUs, 2,592 OTUs classified as fungi, and 95 unidentified OTUs remained. Aside from a few fungal OTUs that could be identified to named species level, the majority of OTUs could not be identified further than family or order. Nonetheless, 85 OTUs were listed as those from the Glomeromycota. All four orders of Glomeromycetes (Glomerales, Paraglomarales, Diversisporales and Archaeosporales) were found in both South Terras and Needle's Eye samples (Fig. 5). Arbuscular mycorrhizal fungal species of Rhizophagus irregularis (formerly Glomus intraradices), Glomus macrocarpum, Paraglomus laccatum, Claroideoglomus etunicatum and Claroideoglomus drummondii were amongst the named species detected. The profile of AM fungi associated with each plant species was distinct (Fig. 5). 
381 Tissue concentrations of essential elements and three non-essential elements (As, $\mathrm{Pb}, \mathrm{Sn})$ for each collected plant species were determined (Table S4). All macro-elements (Ca, K, $\mathrm{Mg}, \mathrm{P}, \mathrm{S})$ and micro-elements $(\mathrm{Cu}, \mathrm{Fe}, \mathrm{Mn}, \mathrm{Zn})$ from nearly all samples from South Terras and Needle's Eye were within the range of typical plant values (Djingova et al., 2013). There was no evidence of mineral deficiency for any samples and a few samples of $C$. oppositifolium and I. pseudacorus from Needle's Eye had particularly high concentrations of $\mathrm{Mn}$ and $\mathrm{Zn}$. Micro-element concentrations were highly varied within plant tissues from some individual samples and, for most species root concentrations, were significantly higher than above-ground tissue concentrations (Table S4). For example, the concentrations of As and $\mathrm{Pb}$ from the roots of samples from both South Terras and Needle's Eye were substantial,


the South Terras plants than those from Needle's Eye. Concentrations of Sn were low in many samples and there was no significant difference between field locations.

${ }^{238} \mathrm{U}$ values within all tissues (Table S4) were substantially above the typical (0.005-

$0.06 \mathrm{\mu g} \mathrm{g}^{-1}$ ) plant concentration range (Djingova et al., 2013). A. scolopendrium showed very high root ${ }^{238} \mathrm{U}$ concentrations of $31-47 \mu \mathrm{g} \mathrm{g}^{-1}$ (Table S4). Similarly, P. vulgaris samples had high root ${ }^{238} \mathrm{U}$ concentrations up to $17 \mu \mathrm{g} \mathrm{g}^{-1}$, whilst above-ground concentrations did not exceed $4 \mu \mathrm{g} \mathrm{g}^{-1}$. The Needle's Eye plants, such as $C$. oppositifolium from site N6, also had high concentrations of root-localised ${ }^{238} \mathrm{U}$ while leaf and stem/petiole concentrations were much lower. In contrast, I. pseudacorus had relatively low concentrations of ${ }^{238} \mathrm{U}$ in stems (up to $0.26 \mu \mathrm{g} \mathrm{g}^{-1}$ ) and roots $\left(\leq 2.5 \mu \mathrm{g} \mathrm{g}^{-1}\right.$ ). In nearly all samples, the amounts of ${ }^{238} \mathrm{U}$ in root tissues were substantially greater than from the leaf or stem/petiole tissues (Fig. 6a). Only $I$. pseudacorus from site N5 displayed relatively equal proportions of root and leaf ${ }^{238} \mathrm{U}$ concentration. South Terras samples had mean root ${ }^{238} \mathrm{U}$ concentrations (per dry weight) that were significantly higher than the stem/petiole and leaf values, however, Needle's Eye 406 plants did not show a significant difference in ${ }^{238} \mathrm{U}$ concentration between tissue types. 

partitioning showed that ${ }^{232}$ Th was concentrated in the leaves and stem/petiole tissues for a number of samples while the root ${ }^{232}$ Th concentration proportions were relatively small (Fig. 6b). Overall, neither South Terras nor Needle's Eye plants showed significant differences in the concentration of ${ }^{232} \mathrm{Th}$ between tissue types. Furthermore, ${ }^{232} \mathrm{Th}$ accumulation was generally low in all collected plant samples, with $P$. vulgaris root tissue $\left(0.67 \mu \mathrm{g} \mathrm{g}^{-1}\right)$ and $O$. crocata leaf tissue $\left(0.71 \mathrm{Mg} \mathrm{g}^{-1}\right)$ having low but detectable concentrations, while the majority of $C$. oppositifolium tissue concentrations were below detectable limits (Table S4). In general, ${ }^{226} \mathrm{Ra}$ accumulated more in root tissues than in above-ground tissues although this pattern of plant tissue partitioning was not as distinct as for ${ }^{238} \mathrm{U}$ (Fig. 6c). There was high variation in ${ }^{226} \mathrm{Ra}$ concentrations between many samples of the same species; for example, $P$. vulgaris from sites $\mathrm{S} 2$ and $\mathrm{S} 5$ showed values of $>15 \mathrm{kBq} \mathrm{kg}^{-1}$, whilst $P$. vulgaris roots from sites S1 and S4 had approximately $1 \mathrm{kBq} \mathrm{kg}^{-1226} \mathrm{Ra}$. I. pseudacorus from site N3 had ${ }^{226} \mathrm{Ra}$ concentrations in the leaf, stem/petiole and root that ranged from $4.65-11.50 \mathrm{kBq} \mathrm{kg}^{-1}$, yet $I$. pseudacorus samples from other sites did not exceed $2.37 \mathrm{kBq} \mathrm{kg}^{-1}$. A. scolopendrium also displayed very low or below detectable ${ }^{226} \mathrm{Ra}$ activities (Table S4).

\subsection{Radionuclide soil to plant transfer factors}

TFs from soil-to-root, soil-to-stem/petiole and soil-to-leaf for each individual plant sample were calculated on a dry weight basis. TF values for ${ }^{238} U$ were much higher $(P<0.015)$ for soil-to-root compared with the ratios from soil-to-above-ground tissues for the South Terras plant samples (Fig. 7). For example, P. vulgaris and A. scolopendrium root tissues had TF values up to 0.37 , whilst no stem/petiole or leaf tissue TF was greater than 0.03 and 0.04 , respectively. The soil-to-root ${ }^{238} U$ TFs were considerably higher for the South Terras samples than the Needle's Eye samples, apart from C. oppositifolium from site N6, which gave the highest ${ }^{238} \mathrm{U}$ soil-to-root TF of 0.09 (Fig. 7c). For many Needle's Eye samples, such as I. pseudacorus, the mean soil-to-root TF value was not significantly different to the soil-tostem/petiole or soil-to-leaf TF values. The $C$. oppositifolium sample from site $\mathrm{N} 1$ had much 
greater TF into above-ground tissue in comparison to all other samples. The profile of TFs

436 for ${ }^{232}$ Th were quite different from those obtained for ${ }^{238} \mathrm{U}$ (Fig. 7). The soil-to-leaf, soil-to-

437 stem and soil-to-root TFs were not significantly different $(P>0.05)$, with the majority of samples having TFs less than 0.2 , regardless of tissue type. However, the combined $O$. crocata sample had considerably higher soil-to-leaf ${ }^{232} \mathrm{Th}$ TF values. The ${ }^{238} \mathrm{U}$ and ${ }^{232} \mathrm{Th} \mathrm{TFs}$ did not indicate any clear differences on the basis of species. However, for the ${ }^{226}$ Ra TFs, all three I. pseudacorus samples had elevated ${ }^{226}$ Ra TF values (Fig. 7), whereas most of the other samples from Needle's Eye and South Terras had ${ }^{226}$ Ra TFs that were below these ranges.

\subsection{Abiotic factors potentially influencing radionuclide bioaccumulation}

PCA was performed to ascertain whether specific abiotic and biotic factors of the soils within the rhizosphere were important in influencing ${ }^{238} \mathrm{U},{ }^{232} \mathrm{Th}$ and ${ }^{226} \mathrm{Ra}$ bioaccumulation. The root ${ }^{238} \mathrm{U}$ PCA plot shows clearly separate clustering of the South Terras and Needle's Eye plant samples, primarily on the basis of PC1 (Fig. 8a). Not all of the samples of the same species were grouped together. For example, $P$. vulgaris from sites S1 and S4 were positioned either side of the remaining South Terras samples, which were more closely clustered. As shown in the corresponding eigenvector loadings (Table S5), TOC was the main driving factor behind PC1, which explained $45.1 \%$ of the variation. Soil $\mathrm{pH}$ and soil concentrations of $\mathrm{Ca}, \mathrm{K}, \mathrm{Fe}, \mathrm{Zn}$ and $\mathrm{SO}_{4}{ }^{2-}$ also were significant factors behind $\mathrm{PC} 1$.

Differences between samples within the South Terras and Needle's Eye locations were due mainly to PC2, which explained $17.3 \%$ of the variation. The main factor underlying PC2 was soil $\mathrm{PO}_{4}{ }^{3-}$ concentration, but root ${ }^{238} \mathrm{U}$ concentration and soil concentrations of ${ }^{238} \mathrm{U}, \mathrm{Cu}, \mathrm{Mn}$, and $\mathrm{NO}_{3}{ }^{-}$also contributed. Individual linear regression analysis examined the relationships between root ${ }^{238} \mathrm{U}$ concentration and key abiotic factors identified by the PCA. Only five abiotic factors, $\mathrm{Cu}, \mathrm{Pb}$ (Fig. 9a), $\mathrm{K}_{1} \mathrm{NO}_{3}{ }^{-}$, and soil pH (Fig. S2), showed significant correlation

$461(r \geq 0.5)$ with root ${ }^{238} \mathrm{U}$ concentration, with soil Cu showing the strongest correlation $\left(R^{2}=\right.$ 462 $0.65 ; r=0.81 ; P=0.005)$, followed by soil $P b\left(R^{2}=0.41 ; r=0.64 ; P=0.047\right)$. There was no 
significant correlation between soil ${ }^{238} \mathrm{U}$ and plant ${ }^{238} \mathrm{U}$ concentration (Fig. 9a). TOC gave a weak correlation with root ${ }^{238} \mathrm{U}$ concentration $(r=-0.38)$ yet there was a stronger correlation between TOC and root ${ }^{238} \cup$ TF $\left(R^{2}=0.58 ; r=-0.76 ; P=0.01\right)$ (Fig. S2). Despite soil $\mathrm{PO}_{4}{ }^{3-}$ showing a poor correlation with root ${ }^{238} \mathrm{U}(\mathrm{r}=0.26)$, soil $\mathrm{PO}_{4}{ }^{3-}$ gave a very strong positive correlation with soil ${ }^{238} U\left(R^{2}=0.69 ; r=0.83 ; P=0.003\right)$ (Fig. S2).

The ${ }^{232} \mathrm{Th}$ (Fig. 8b) and ${ }^{226} \mathrm{Ra}$ (Fig. 8c) PCA plots displayed very similar sample groupings as seen in the ${ }^{238} \mathrm{U}$ plot, whereby South Terras and Needle's Eye samples were separated mostly on the basis of PC1, which in both plots contributed over $42 \%$ of the variation. Soil TOC was the main influencing factor for PC1 in both plots, while the main factors behind $\mathrm{PC} 2$ were soil $\mathrm{PO}_{4}{ }^{3-}$ and $\mathrm{Mn}$ for the ${ }^{232} \mathrm{Th}$ plot and ${ }^{226} \mathrm{Ra}$ plot, respectively (Table S5). PC3 explained $12.8 \%$ of the variation of the ${ }^{232}$ Th PCA, with soil ${ }^{232}$ Th concentration being a main factor of $\mathrm{PC} 3$. Five abiotic factors, soil ${ }^{232} \mathrm{Th}, \mathrm{Ca}, \mathrm{K}, \mathrm{pH} \mathrm{PO}_{4}{ }^{3-}$ and TOC, showed significant correlations with root ${ }^{232}$ Th concentration (Fig. 9b; Fig. S2). The relationship between soil and root ${ }^{232} T h$ was the strongest $\left(R^{2}=0.65 ; r=0.81 ; P=\right.$ 0.005). Similarly, the only positive correlating factor with root ${ }^{226} \mathrm{Ra}$ concentration was with soil ${ }^{226} R a$ concentration $\left(R^{2}=0.70 ; r=0.84 ; P=0.009\right)$, while soil Mg concentration showed a significant negative correlation with root ${ }^{226} \mathrm{Ra}$ concentration (Fig. 9c).

\subsection{The relationships between the degree of $A M$ fungal association and root radionuclide concentration}

The quantified percentage abundance of AM fungal hyphae, arbuscules and vesicles within root tissues (Fig. 4) was also included in each PCA. Overall, the fungal data were not a major influencing factor for the PCA plots, although \% arbuscules was a key factor underpinning PC3 (explaining $12-14 \%$ of the variation) for each of the plots (Table S5). Linear regression analysis found no significant correlation for any of the fungal characteristics in relation to root ${ }^{238} \mathrm{U}$ or ${ }^{232} \mathrm{Th}$ concentration (Fig. 10). In contrast there was a significant negative correlation between the abundance of AM fungal structures and root 
${ }^{226} \mathrm{Ra}$ concentration (Fig. 10c), particularly on the basis of hyphal abundance $\left(R^{2}=0.44 ; r=-\right.$ $0.66 ; P=0.042)$

492

\section{Discussion}

494

South Terras and Needle's Eye are two ideal field locations for the characterisation of

radionuclide transfer from soil into the understory vegetation of temperate woodland. While there has previously been substantial radiochemistry research at Needle's Eye and, to a lesser extent, South Terras (Basham et al., 1991; Corkhill et al., 2017; Foulkes et al., 2017; MacKenzie et al., 1991; Siddeeg et al., 2015), no previous study has investigated the radioecology of these sites. Both locations have soils with ${ }^{238} \mathrm{U}$ concentrations that greatly exceed the global average (UNSCEAR, 2000) and were similar to or exceeded values determined by a number of radioecology surveys (Blanco Rodriguez et al., 2010; Favas et al., 2016; Vera Tomé et al., 2003; Vera Tomé et al., 2002). The ${ }^{226}$ Ra concentrations reported here were also highly elevated above the natural range reported by the IAEA (2003). In contrast, soil concentrations of ${ }^{232} \mathrm{Th}$ from both environments were in the lower range of natural background soil (IAEA, 2003), as would be expected since both sites have $\mathrm{U}$, but not Th, mineralisation. This may explain the fairly low abundance of ${ }^{232} \mathrm{Th}$ seen in the plant tissues, such as the $C$. oppositifolium samples, which may be low because of the poor environmental mobility of ${ }^{232} \mathrm{Th}(\mathrm{IV})$. Very few publications have studied plant ${ }^{232} \mathrm{Th}$ bioaccumulation, but samples from South Terras and Needle's Eye displayed bioaccumulation characteristics that were consistent with another study (Vera Tomé et al., 2002). In contrast, plant ${ }^{238} \mathrm{U}$ and ${ }^{226} \mathrm{Ra}$ bioaccumulation has been more widely examined (Al-Hamarneh et al., 2016; Amaral et al., 2005; Favas et al., 2016; Soudek et al., 2007; Vera

514 Tomé et al., 2002), and the concentrations seen here in above-ground tissues were within similar ranges to those observed before. However, apart from some exceptions (Cordeiro et al., 2016; Favas et al., 2016), few other studies have quantified radionuclide bioaccumulation and partitioning into roots of non-crop plant species as performed here. This has important 
implications as it allows better consideration of the low risks of further trophic transfer if the bulk of the accumulated radionuclides is actually retained within the root tissues.

Although there are significantly elevated radionuclide concentrations at both South Terras and Needle's Eye, soil chemistry conditions were very different, particularly with regard to TOC. This provided an ability to evaluate potential differences in radionuclide bioaccumulation on the basis of different soil abiotic factors under natural field conditions. For example, high levels of organic matter are predicted to cause significant retardation of ${ }^{238} \mathrm{U}$ due to the prevalence of more insoluble and immobile ${ }^{238} \mathrm{U}(\mathrm{IV})$ rather than the more mobile ${ }^{238} \mathrm{U}(\mathrm{VI})$ (Basham et al., 1991; MacKenzie et al., 1991; Mitchell et al., 2013). Therefore ${ }^{238} \mathrm{U}$ from the organic-rich bog zone at Needle's Eye would be less bioavailable for plant uptake despite the high concentration of ${ }^{238} \mathrm{U}$ in the Needle's Eye soils. Moreover, a high concentration of humic substances in an organic soil will provide a greater abundance of negatively charged binding sites for the sorption of cations, such as the free uranyl ion $\left(\mathrm{UO}_{2}{ }^{2+}\right)$, further reducing the quantity of ${ }^{238} \mathrm{U}$ bioavailable to plants (Ebbs et al., 1998; Mitchell et al., 2013). This may in part explain the clear variation seen in ${ }^{238} \mathrm{U}$ root bioaccumulation between the two sets of plants from the different field sites as quantified on the basis of soil-to-root TF. However, there is the caveat that the two sets of plants were made up of different species as a common dominant species was not present at both field sites. Future research should perform controlled experiments with the same plant species cultivated in South Terras and Needle's Eye soil to validate this conclusion.

TF values are commonly used as a means to assess toxic metal and radionuclide bioaccumulation. All of the TFs calculated for South Terras and Needle's Eye plant species were within the ranges seen previously for plant species in a temperate environment (AlHamarneh et al., 2016; IAEA, 2003). However, the ${ }^{238} U$ TF values for soil-to-leaf and soil-tostem were mostly quite low $(<0.05)$, which is also consistent with the analysis of multiple plant species from a uranium mine site in Portugal (Favas et al., 2016), whilst previous analysis of flora from other former uranium contaminated sites found ${ }^{238} \mathrm{U} T F$ into aboveground tissue of >0.3 (Blanco Rodriguez et al., 2010; Vera Tomé et al., 2002). Indeed one 
study identified a sample of Rorippa sylvestris (creeping yellowcress) with significantly high

547 uranium transfer into the shoots with a mean TF value of 680 (Cordeiro et al., 2016).

548 Although most previous studies did not determine soil-to-root TFs, we observed substantial root retention of ${ }^{238} \mathrm{U}$ in nearly all samples, which is consistent with lower TF values into above-ground tissues. Because it is extremely difficult to remove all soil particles from root tissues, caution should often be made in the interpretation of root values from soil-grown plants. Here the 'root' ${ }^{238} \mathrm{U}$ values were adjusted using a Ti correction factor to take any remnant soil left on the plant tissue into account (Cook et al., 2009), therefore these ${ }^{238} \mathrm{U}$ root retention values were accepted with greater confidence. This root retention profile is fully consistent with that seen in another recent examination of 53 native plant species (Favas et al., 2016). This root retention of ${ }^{238} \mathrm{U}$ may suggest a reduced concern regarding further ecosystem transfer of the radionuclide through animal or insect herbivory. Furthermore, high concentrations of radionuclides within plant roots may be a concern for soil animals and microorganisms that feed on plant root biomass. ${ }^{226}$ Ra TFs were much higher than for ${ }^{232} \mathrm{Th}$ and ${ }^{238} \mathrm{U}$, which could be the result of higher solubility. ${ }^{226} \mathrm{Ra}$ may accumulate as $\mathrm{Ra}^{2+}$ through uptake pathways for $\mathrm{Ca}^{2+}$, an essential ion required on a large scale by plants (Skoko et al., 2017; Vera Tomé et al., 2003). This could also explain why ${ }^{226}$ Ra tissue partitioning was not distinctive.

Multiple abiotic factors are likely to influence radionuclide TFs and the overall mobility of radionuclides. PCA validated TOC as a major influencing factor behind the variation in root concentrations of ${ }^{238} \mathrm{U},{ }^{232} \mathrm{Th}$ and ${ }^{226} \mathrm{Ra}$. Linear regression of soil TOC relative to total $\operatorname{root}^{238} \mathrm{U}$ concentration gave a weak correlation, although the relationship was much stronger when ${ }^{238} \mathrm{U}$ TF was considered. Other factors in addition to TOC may contribute to ${ }^{238} \mathrm{U}$ bioaccumulation characteristics in these environments. Previous research has identified factors including soil $\mathrm{pH}$, cation exchange capacity, organic matter, particle size distribution,

$571 \mathrm{Ca}^{2+}, \mathrm{K}^{+}$and $\mathrm{PO}_{4}{ }^{3-}$ concentration that can affect ${ }^{238} \mathrm{U}$ bioaccumulation, in part due to changes to its oxidation state (Boghi et al., 2018; Chen et al., 2005c; Ebbs et al., 1998;

573 Gupta et al., 2016; Pulhani et al., 2005; Rodriguez et al., 2017). PCA indicated soil pH as a 
key factor. Based on previous modelling (Ebbs et al., 1998), free uranyl cations are predicted to be prevalent in South Terras soil ( $\mathrm{pH}$ range 4.5 - 5.6), while at Needle's Eye ( $\mathrm{pH}$ range 5.2 - 6.4) U-hydroxides and U-carbonates are predicted to be more highly abundant, but these are less readily bioavailable (Ebbs et al., 1998; Vandenhove et al., 2007). The negative correlation of soil pH versus ${ }^{238} \mathrm{U}$ root concentration supports this.

It was interesting to observe strong positive correlations for root ${ }^{238} \mathrm{U}$ concentration with soil $\mathrm{Cu}$ and $\mathrm{Pb}$. It is clear that there is a phylogenetic basis to plant species-specific variation in element and radionuclide concentrations within tissues (Broadley et al., 2004; Willey, 2010). Although phylogenetic variation in plant $U$ concentration is yet to be fully understood (Watanabe et al., 2007), the correlation between $\mathrm{Cu}, \mathrm{Pb}$ and $\mathrm{U}$ may have a phylogenetic basis. Soil chemistry characteristics may also underpin the correlation. It has been observed that $U$ minerals at South Terras are Cu-phosphate and Cu-arsenate rich, such as metatorbernite and metazeunerite, and were present at depths of $\sim 25 \mathrm{~cm}$ (Corkhill et al., 2017; Foulkes et al., 2017; Purvis et al., 2004), consistent with the rhizosphere soils analysed here. In addition to a close association between $\mathrm{U}, \mathrm{Cu}$ and $\mathrm{P}$ in these soils, $\mathrm{Cu}$ and P showed similar chemical behaviour to $U$ as determined by sequential extraction analysis (Corkhill et al., 2017). Therefore plant roots and/or mycorrhizal hyphae accessing essential $\mathrm{Cu}$ and $\mathrm{PO}_{4}{ }^{3-}$ nutrients from the soil might coincidentally bioaccumulate ${ }^{238} \mathrm{U}$. Likewise, as a result of similarity in behaviour of $\mathrm{U}$ and $\mathrm{Pb}$ interactions with dissolved organic compounds (Dessureault-Rompre et al., 2008; Pedrot et al., 2008), these elements could be coincidentally bioaccumulated by a plant, although the precise molecular pathway underlining $U$ uptake in plant roots remains unknown. Both of these hypotheses need testing in the future. However, while the South Terras samples displayed significant $\mathrm{Cu}, \mathrm{Pb}$ and $\mathrm{U}$ root tissue partitioning, the Needle's Eye samples, with much reduced soil-to-root ${ }^{238} \mathrm{U}$ transfer, did not share this pattern, suggesting that soil characteristics may be particularly important.

There were fewer significant correlations between ${ }^{226} \mathrm{Ra}$ or ${ }^{232} \mathrm{Th}$ and other factors.

This may be unsurprising as these radionuclides are less complicated than ${ }^{238} \mathrm{U}$ with regard 
602 to redox chemistry. Soil Mg was weakly correlated with root ${ }^{226} \mathrm{Ra}$ concentration, supporting

603 suggestions of a competitive interaction between these cations (Mitchell et al., 2013).

604 However, the strongest correlation for root ${ }^{226} \mathrm{Ra}$ concentration was with soil ${ }^{226} \mathrm{Ra}$

605 concentration, which contradicts previous findings (Bettencourt et al., 1988; Blanco

606 Rodriguez et al., 2010; Hu et al., 2014). In contrast, significant correlations between root

$607{ }^{232}$ Th and soil Ca or K were in support of previous discussions (Pulhani et al., 2005). The data also support the proposition that Th adsorption to organic matter is positively related to increasing $\mathrm{pH}$, inferring that bioavailability of ${ }^{232} \mathrm{Th}$ would decrease with increasing $\mathrm{pH}$ in the presence of organic materials (Syed, 1999).

Microbial influences on radionuclide bioaccumulation into plants must be considered, including the potential role of AM fungi (Davies et al., 2015). A key aim of this study was therefore to determine the root mycorrhizal status of the collected plants by quantification of AM fungal association and fungal species identification. It is clear that AM fungi can form associations with the roots of all of the plant species sampled, although each plant species displayed distinct fungal community structures. This included $O$. crocata, which is not usually considered as mycorrhizal (Harley and Harley, 1987). Previous research has demonstrated the ability of $\mathrm{AM}$ fungi to increase the transfer of ${ }^{238} \mathrm{U}$ into plants and to increase the retention of ${ }^{238} \mathrm{U}$ in roots (Chen et al., 2008; Chen et al., 2005a; Chen et al., 2005b; Rufyikiri et al., 2004; Rufyikiri et al., 2003; Rufyikiri et al., 2002). These predominantly laboratorybased studies typically used a single AM fungal species, $R$. irregularis, alongside a single plant species, such as carrot. In contrast, there was no significant correlation between abundance of $A M$ fungi and ${ }^{238} \mathrm{U}$ transfer into the roots of the field samples. Molecular identification of the fungi confirmed that multiple AM fungal taxa were associated with each plant, questioning the validity of the previous single species interaction studies. $R$. irregularis was detected within plant roots in the field at both South Terras and Needle's Eye alongside other AM fungi. While one or more of these AM fungi might contribute to the significant ${ }^{238} \mathrm{U}$ root partitioning seen in the field plant samples, it is clear that interpretation of field-scale data involving different plant species associated with a community of AM fungal taxa is very 
challenging. A primary role of $\mathrm{AM}$ fungi is the assimilation and transfer of $\mathrm{PO}_{4}{ }^{3-}$ from the soil and into the associated plant, but in a typical deciduous woodland there is substantial functional diversity between different $\mathrm{AM}$ fungal species displaying distinct $\mathrm{PO}_{4}{ }^{3-}$ transfer characteristics (Helgason et al., 2002). It is equally likely that transfer characteristics of ${ }^{238} \mathrm{U}$ will differ between $\mathrm{AM}$ fungal species, particularly if co-uptake of ${ }^{238} \mathrm{U}$ with $\mathrm{PO}_{4}{ }^{3-}$ may occur (Chen et al., 2005b; Davies et al., 2015; Rufyikiri et al., 2004; Vandenhove et al., 2007). Therefore future experiments may need to isolate fungal species from uranium contaminated field sites and evaluate ${ }^{238} \mathrm{U}$ transfer efficiencies of native species under controlled conditions.

To date there has been little study of AM fungi in relation to ${ }^{232} \mathrm{Th}$, however, it has been previously observed that in the presence of $R$. irregularis, Medicago truncatula plants showed reduced shoot concentration of ${ }^{232}$ Th but the fungi had no influence on root concentration of the radionuclide (Roos and Jakobsen, 2008). Likewise, there was no significant correlation between abundance of AM fungi and ${ }^{232}$ Th transfer into the roots of the field samples. The possible relationship between plant-AM fungi association and ${ }^{226} \mathrm{Ra}$ transfer is unstudied. Here a significant negative correlation was observed between ${ }^{226} \mathrm{Ra}$ transfer and fungal hyphae abundance, indicating the possibility that fungal association may buffer against ${ }^{226} \mathrm{Ra}$ accumulation into the plant. AM fungi have been shown to protect plants against toxic concentrations of metals such as $\mathrm{Cu}, \mathrm{Pb}$ and $\mathrm{Cd}$ by restricting root and shoot accumulation (Hristozkova et al., 2016; Zhou et al., 2017).

In conclusion, we have presented the first data regarding plant uptake of ${ }^{238} \mathrm{U},{ }^{232} \mathrm{Th}$ and ${ }^{226} \mathrm{Ra}$ from two significant radionuclide-rich environments in the UK. Native plants displayed elevated concentrations of these radionuclides, particularly ${ }^{238} \mathrm{U}$, which was highly partitioned in plant roots. We indicate that abiotic factors including TOC may be a key influence on radionuclide transfer. We also show that AM fungi are prevalent in these environments and suggest that the study of plant-fungal association in the context of radionuclide bioaccumulation at field scale is challenging and will require a better understanding of fungal community dynamics. 


\section{Acknowledgments}

660

661

662

663

664

665

666

667

668

669

670

671

672

673

674

675

676

677

We are grateful to Natural Environment Research Council, Radioactivity and the Environment (RATE) programme, LO-RISE consortium (grant number: NE/L000547/1) for project funding. H.S.D. was supported by an EPSRC Nuclear FiRST DTC PhD studentship (grant number EP/G037140/1), and J.R.M. was supported by CONACyT MSc and PhD studentship funding from the Mexican government. We thank the Boconnoc Estate, Lostwithiel, Cornwall, UK for allowing access to the South Terras site. Rainfall and temperature data was provided by the Centre for Ecology and Hydrology and the UK Met Office, respectively. We are grateful to Christopher Walker for advice and comments on AM fungal identification. We also thank Katie Law, Hamza Al-qasmi, Gareth Law and Adam Fuller for assistance with gamma spectroscopy and other radiochemical analyses.

\section{Conflicts of interest}

There are no conflicts of interest in this work.

\section{References}

Al-Hamarneh IF, Alkhomashi N, Almasoud FI. Study on the radioactivity and soil-to-plant transfer factor of $\mathrm{Ra}-226, \mathrm{U}-234$ and $\mathrm{U}-238$ radionuclides in irrigated farms from the northwestern Saudi Arabia. Journal of Environmental Radioactivity 2016; 160: 1-7.

Al-Kharouf SJ, Al-Hamarneh IF, Dababneh M. Natural radioactivity, dose assessment and uranium uptake by agricultural crops at Khan Al-Zabeeb, Jordan. Journal of Environmental Radioactivity 2008; 99: 1192-1199.

Allen ES. Chemical Analysis of Ecological Materials. Blackwell Scientific, Oxford, 1974.

Amaral RD, de Vasconcelos WE, Borges E, Silveira SV, Mazzilli BP. Intake of uranium and radium-226 due to food crops consumption in the phosphate region of Pernambuco Brazil. Journal of Environmental Radioactivity 2005; 82: 383-393. 
Basham I, Milodowski A, Hyslop E, Pearce J. The location of uranium in source rocks and sites of secondary deposition at the Needle's Eye natural analogue site, Dumfries and Galloway. Nuclear Science and Technology Report EUR 13279. Commission of the European Communities, Luxembourge, 1991, pp. 1-56.

Bettencourt AO, Teixeira M, Elias MDT, Faisca MC. Soil to plant transfer of Ra-226. Journal of Environmental Radioactivity 1988; 6: 49-60.

Blanco Rodriguez P, Vera Tome F, Lozano JC, Perez Fernandez MA. Transfer of U-238, Th230, Ra-226, and $\mathrm{Pb}-210$ from soils to tree and shrub species in a Mediterranean area. Applied Radiation and Isotopes 2010; 68: 1154-1159.

Boghi A, Roose T, Kirk GJD. A model of uranium uptake by plant roots allowing for rootinduced changes in the soil. Environmental Science \& Technology 2018; in press.

Broadley MR, Bowen HC, Cotterill HL, Hammond JP, Meacham MC, Mead A, et al. Phylogenetic variation in the shoot mineral concentration of angiosperms. Journal of Experimental Botany 2004; 55: 321-336.

Caporaso JG, Kuczynski J, Stombaugh J, Bittinger K, Bushman FD, Costello EK, et al. QIIME allows analysis of high-throughput community sequencing data. Nature Methods 2010; 7: 335-336.

Chen B, Roos P, Zhu Y-G, Jakobsen I. Arbuscular mycorrhizas contribute to phyto stabilization of uranium in uranium mining tailings. Journal of Environmental Radioactivity 2008; 99: 801-810.

Chen BD, Jakobsen I, Roos P, Zhu YG. Effects of the mycorrhizal fungus Glomus intraradices on uranium uptake and accumulation by Medicago truncatula L. from uranium-contaminated soil. Plant and Soil 2005a; 275: 349-359.

Chen BD, Roos P, Borggaard OK, Zhu YG, Jakobsen I. Mycorrhiza and root hairs in barley enhance acquisition of phosphorus and uranium from phosphate rock but mycorrhiza decreases root to shoot uranium transfer. New Phytologist 2005b; 165: 591-598. 
Chen SB, Zhu YG, Hu QH. Soil to plant transfer of U-238 Ra-226 and Th-232 on a uranium mining-impacted soil from southeastern China. Journal of Environmental Radioactivity 2005c; 82: 223-236.

Cook LL, McGonigle TR, Inouye RS. Titanium as an indicator of residual soil on arid-land plants. Journal of Environmental Quality 2009; 38: 188-199.

Cordeiro C, Favas PJC, Pratas J, Sarkar SK, Venkatachalam P. Uranium accumulation in aquatic macrophytes in an uraniferous region: Relevance to natural attenuation. Chemosphere 2016; 156: 76-87.

Corkhill CL, Crean DE, Bailey DJ, Makepeace C, Stennett MC, Tappero R, et al. Multi-scale investigation of uranium attenuation by arsenic at an abandoned uranium mine, South Terras. npj Materials Degradation 2017; $1: 19$.

Davies HS, Cox F, Robinson CH, Pittman JK. Radioactivity and the environment: technical approaches to understand the role of arbuscular mycorrhizal plants in radionuclide bioaccumulation. Frontiers in Plant Science 2015; 6: 580.

de Vere N, Rich T, Ford C, Trinder S, Long C, Moore C, et al. DNA barcoding the native flowering plants and conifers of Wales. PLoS One 2012; 7: e37945.

Dessureault-Rompre J, Nowack B, Schulin R, Tercier-Waeber ML, Luster J. Metal solubility and speciation in the rhizosphere of Lupinus albus cluster roots. Environmental Science \& Technology 2008; 42: 7146-7151.

Djingova R, Mihaylova V, Lyubomirova V, Tsalev DL. Multielement analytical spectroscopy in plant ionomics research. Applied Spectroscopy Reviews 2013; 48: 384-424.

Ebbs SD, Brady DJ, Kochian LV. Role of uranium speciation in the uptake and translocation of uranium by plants. Journal of Experimental Botany 1998; 49: 1183-1190.

Edgar RC. Search and clustering orders of magnitude faster than BLAST. Bioinformatics 2010; 26: 2460-2461.

Edgar RC, Haas BJ, Clemente JC, Quince C, Knight R. UCHIME improves sensitivity and speed of chimera detection. Bioinformatics 2011; 27: 2194-2200. 
Favas PJC, Pratas J, Mitra S, Sarkar SK, Venkatachalam P. Biogeochemistry of uranium in the soil-plant and water-plant systems in an old uranium mine. Science of The Total Environment 2016; 568: 350-368.

Foulkes M, Millward G, Henderson S, Blake W. Bioaccessibility of U, Th and Pb in solid wastes and soils from an abandoned uranium mine. Journal of Environmental Radioactivity 2017; 173: 85-96.

Gupta D, Chatterjee S, Datta S, Voronina A, Walther C. Radionuclides: Accumulation and Transport in Plants. Reviews of Environmental Contamination and Toxicology. 241. Springer, Switzerland, 2016, pp. 139-160.

Harley JL, Harley EL. A checklist of mycorrhiza in the British Flora - addenda, errata and index. New Phytologist 1987; 107: 741-749.

Harrison MJ. The arbuscular mycorrhizal symbiosis: An underground association. Trends in Plant Science 1997; 2: 54-60.

Harrison MJ, Dewbre GR, Liu JY. A phosphate transporter from Medicago truncatula involved in the acquisiton of phosphate released by arbuscular mycorrhizal fungi. Plant Cell 2002; 14: 2413-2429.

Helgason T, Merryweather JW, Denison J, Wilson P, Young JPW, Fitter AH. Selectivity and functional diversity in arbuscular mycorrhizas of co-occurring fungi and plants from a temperate deciduous woodland. Journal of Ecology 2002; 90: 371-384.

Hristozkova M, Geneva M, Stancheva I, Boychinova M, Djonova E. Contribution of arbuscular mycorrhizal fungi in attenuation of heavy metal impact on Calendula officinalis development. Applied Soil Ecology 2016; 101: 57-63.

Hu N, Ding D, Li G, Zheng J, Li L, Zhao W, et al. Vegetation composition and Ra-226 uptake by native plant species at a uranium mill tailings impoundment in South China. Journal of Environmental Radioactivity 2014; 129: 100-106.

IAEA. Measurement of Radionuclides in Food and the Environment. Technical Report Series No. 295, Vienna, 1989. 
IAEA. Handbook of parameter values for the prediction of radionuclide transfer in temperate environments- in collaboration with the Union of Radioecologists. Technical Report. 364, 1994.

IAEA. Extent of environmental contamination by naturally occurring radioactive materials (NORM) and technological options for mitigation. Technical Report Series. 319, 2003.

IAEA. Quantification of radionuclide transfer in terrestrial and freshwater environments for radiological assessment. IAEA Technical Document. 1616, 2009.

Jung S, Marron JS. PCA consistency in high dimension, low sample size context. Annals of Statistics 2009; 37: 4104-4130.

Karunakara N, Rao C, Ujwal P, Yashodhara I, Kumara S, Ravi PM. Soil to rice transfer factors for Ra-226, Ra-228, (210)pb, K-40 and Cs-137: a study on rice grown in India. Journal of Environmental Radioactivity 2013; 118: 80-92.

Koske RE, Gemma JN. A modified procedure for staining roots to detect VA-mycorrhizas. Mycological Research 1989; 92: 486-505.

Krause PD. Statistical-analysis of pH data. Anesthesia and Analgesia 1978; 57: 143-144.

Krug FJ, Ruzicka J, Hansen EH. Determination of ammonia in low concentrations with Nessler's reagent by flow injection analysis. Analyst 1979; 104: 47-54.

Lodhi MA, Ye G-N, Weeden NF, Reisch BI. A simple and efficient method for DNA extraction from grapevine cultivars and Vitis species. Plant Molecular Biology Reporter 1994; 12: 6-13.

MacKenzie A, Whitton A, Shimmield T, Jamielita R, Scott R, Hooker P. Natural decay series radionuclide studies at the Needle's Eye natural analogue site, II, 1989-1991. In: BGS, editor. Fluid Process Group Technical Report WE/91/37. British Geological Survey, Nottingham, 1991, pp. 1- 86.

Malin SA, Petrzelka P. Left in the dust: uranium's legacy and victims of mill tailings exposure in Monticello, Utah. Society \& Natural Resources 2010; 23: 1187-1200. 
McGonigle TP, Miller MH, Evans DG, Fairchild GL, Swan JA. A new method which gives an objective measure of colonization of roots by vesicular arbuscular mycorrhizal fungi. New Phytologist 1990; 115: 495-501.

Mitchell N, Perez-Sanchez D, Thorne MC. A review of the behaviour of U-238 series radionuclides in soils and plants. Journal of Radiological Protection 2013; 33: R17R48.

Newsham KK, Bridge PD. Sebacinales are associates of the leafy liverwort Lophozia excisa in the southern maritime Antarctic. Mycorrhiza 2010; 20: 307-313.

Pedrot M, Dia A, Davranche M, Bouhnik-Le Coz M, Henin O, Gruau G. Insights into colloidmediated trace element release at the soil/water interface. Journal of Colloid and Interface Science 2008; 325: 187-197.

Pulhani VA, Dafauti S, Hegde AG, Sharma RM, Mishra UC. Uptake and distribution of natural radioactivity in wheat plants from soil. Journal of Environmental Radioactivity 2005; 79: 331-346.

Purvis OW, Bailey EH, McLean J, Kasama T, Williamson BJ. Uranium biosorption by the lichen Trapelia involuta at a uranium mine. Geomicrobiology Journal 2004; 21: 159167.

Read D, Hooker PJ, Ivanovich M, Milodowski AE. A Natural Analogue Study of an Abandoned Uranium Mine in Cornwall, England. Radiochimica Acta 1991; 52-53: 349.

Rodriguez PB, Tome FV, Lozano JC. Influence of soil structure on the "F-v approach" applied to U-238 and Ra-226. Chemosphere 2017; 168: 832-838.

Roos P, Jakobsen I. Arbuscular mycorrhiza reduces phytoextraction of uranium, thorium and other elements from phosphate rock. Journal of Environmental Radioactivity 2008; 99: 811-819.

Ross EM, Raj YL, Wesley SG, Rajan MP. Selected natural and fallout radionuclides in plant foods around the Kudankulam Nuclear Power Project, India. Journal of Environmental Radioactivity 2013; 115: 201-206. 
Rufyikiri G, Declerck S, Thiry Y. Comparison of U-233 and P-33 uptake and translocation by the arbuscular mycorrhizal fungus Glomus intraradices in root organ culture conditions. Mycorrhiza 2004; 14: 203-207.

Rufyikiri G, Thiry Y, Declerck S. Contribution of hyphae and roots to uranium uptake and translocation by arbuscular mycorrhizal carrot roots under root-organ culture conditions. New Phytologist 2003; 158: 391-399.

Rufyikiri G, Thiry Y, Wang L, Delvaux B, Declerck S. Uranium uptake and translocation by the arbuscular mycorrhizal fungus, Glomus intraradices, under root-organ culture conditions. New Phytologist 2002; 156: 275-281.

Saenen E, Horemans N, Vanhoudt N, Vandenhove H, Biermans G, Van Hees M, et al. Effects of $\mathrm{pH}$ on uranium uptake and oxidative stress responses induced in Arabidopsis thaliana. Environmental Toxicology and Chemistry 2013; 32: 2125-2133.

Siddeeg SM, Bryan ND, Livens FR. Behaviour and mobility of $U$ and $R a$ in sediments near an abandoned uranium mine, Cornwall, UK. Environmental Science-Processes \& Impacts 2015; 17: 235-245.

Skoko B, Marovic G, Babic D, Sostaric M, Jukic M. Plant uptake of U-238, U-235, Th-232, Ra-226, Pb-210 and K-40 a from a coal ash and slag disposal site and control soil under field conditions: A preliminary study. Journal of Environmental Radioactivity 2017; 172: 113-121.

Soudek P, Petrik P, Vagner M, Tykva R, Plojhar V, Petrova S, et al. Botanical survey and screening of plant species which accumulate Ra-226 from contaminated soil of uranium waste depot. European Journal of Soil Biology 2007; 43: 251-261.

Soudek P, Petrova S, Buzek M, Lhotsky O, Vanek T. Uranium uptake in Nicotiana sp under hydroponic conditions. Journal of Geochemical Exploration 2014; 142: 130-137.

Syed HS. Comparison studies adsorption of thorium and uranium on pure clay minerals and local Malaysian soil sediments. Journal of Radioanalytical and Nuclear Chemistry 1999; 241: 11-14. 
Taylor DL, Walters WA, Lennon NJ, Bochicchio J, Krohn A, Caporaso JG, et al. Accurate estimation of fungal diversity and abundance through improved lineage-specific primers optimized for Illumina amplicon sequencing. Applied and Environmental Microbiology 2016; 82: 7217-7226.

UNSCEAR. Ionizing radiation: sources and effects of ionizing radiation. Report to the general assembly with annexes, United Nations, New York, 2000.

Vandenhove H, Van Hees M, Wannijn J, Wouters K, Wang L. Can we predict uranium bioavailability based on soil parameters? Part 2: Soil solution uranium concentration is not a good bioavailability index. Environmental Pollution 2007; 145: 577-586.

Vera Tomé F, Blanco Rodriguez MP, Lozano JC. Soil-to-plant transfer factors for natural radionuclides and stable elements in a Mediterranean area. Journal of Environmental Radioactivity 2003; 65: 161-175.

Vera Tomé F, Blanco Rodriguez P, Lozano JC. Distribution and mobilization of U, Th and 226Ra in the plant-soil compartments of a mineralized uranium area in south-west Spain. Journal of Environmental Radioactivity 2002; 59: 41-60.

Watanabe T, Broadley MR, Jansen S, White PJ, Takada J, Satake K, et al. Evolutionary control of leaf element composition in plants. New Phytologist 2007; 174: 516-523.

Willey NJ. Phylogeny can be used to make useful predictions of soil-to-plant transfer factors for radionuclides. Radiation and Environmental Biophysics 2010; 49: 613-623.

Winde F, Brugge D, Nidecker A, Ruegg U. Uranium from Africa - An overview on past and current mining activities: Re-appraising associated risks and chances in a global context. Journal of African Earth Sciences 2017; 129: 759-778.

Zhou X, Fu L, Xia Y, Zheng L, Chen C, Shen Z, et al. Arbuscular mycorrhizal fungi enhance the copper tolerance of Tagetes patula through the sorption and barrier mechanisms of intraradical hyphae. Metallomics 2017; 9: 936-948. 


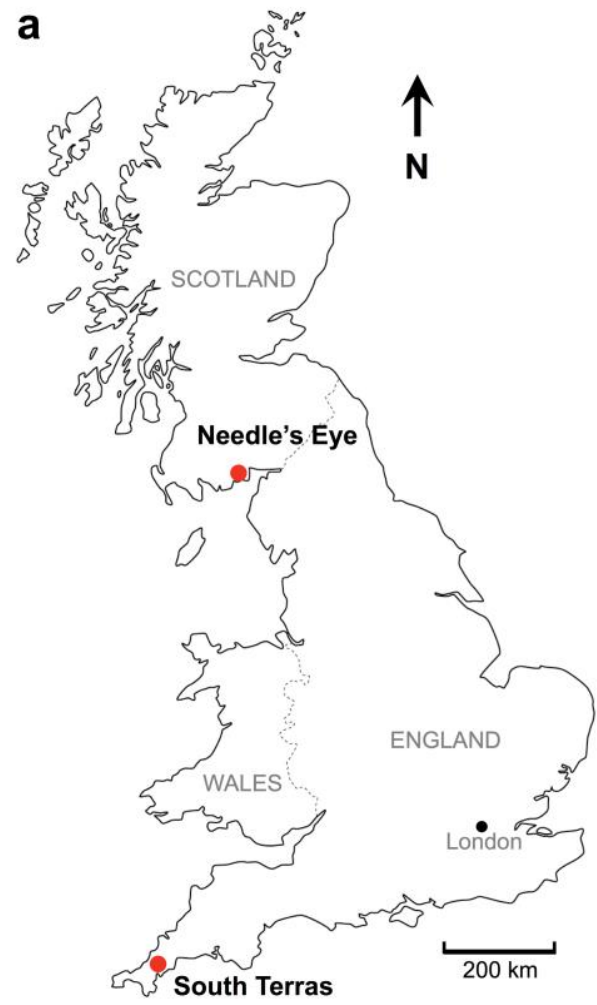

875



\section{South Terras}

Border to old ore processing concrete floor

River Fal

Steep incline

Grass predominant zone

\begin{tabular}{cc}
\hline Site & Plant species collected \\
\hline S1, S2 & $\begin{array}{c}\text { Asplenium } \\
\text { scolopendrium L. }\end{array}$ \\
S1, S2, S4, S5 & Primula vulgaris Huds. \\
\hline
\end{tabular}

Grid Ref: lat. $50^{\circ} 20^{\prime} 06^{\prime \prime} \mathrm{N}$, long. $4^{\circ} 54^{\prime} 17^{\prime \prime} \mathrm{W}$

\section{Needle's Eye}

- The Needle's Eye natural rock arch

Urananite vein exposed in cliff face

Transition into organic bog zone

Rocky outcrop

\begin{tabular}{cc}
\hline Site & Plant species collected \\
\hline N1, N4, N6 & $\begin{array}{c}\text { Chrysosplenium } \\
\text { oppositifolium L. }\end{array}$ \\
N2, N3, N5 & Iris pseudacorus L. \\
N7, N8, N9 & Oenanthe crocata L. \\
\hline
\end{tabular}

Grid Ref: lat. $54^{\circ} 53^{\prime} 19^{\prime \prime} \mathrm{N}$, long. $3^{\circ} 41^{\prime} 30^{\prime \prime} \mathrm{W}$



Fig. 1. Sampling sites and summary of collected plant species at South Terras (Cornwall, UK) and Needle's Eye (Scotland, UK). (a) Location of the South Terras and Needle's Eye sites within the UK. (b) Sampling at South Terras took place at the site of the old ore processing floor (OPF) and from the area near the old chimney stack (NC). (c) Sampling at Needle's Eye predominantly took place in a bog area adjacent to the cliff face. Maps were created by the authors using Digimap Ordinance Survey data and Aerial Digimap data (https://digimap.edina.ac.uk/), and field survey measurements. 



Fig. 2. Soil chemistry characteristics and soil ${ }^{238} \mathrm{U},{ }^{232} \mathrm{Th}$ and ${ }^{226} \mathrm{Ra}$ concentrations from South Terras (ST) and Needle's Eye (NE). (a) pH, (b) TOC, and (c - f) macronutrients, and $(\mathrm{g}-\mathrm{i})$ radionuclides. Boxes show the $25^{\text {th }}$ and $75^{\text {th }}$ percentiles, the line within the boxes shows the median values, and the whisker bars show minimum and maximum values $((a-f$, i) $n=6-9 ;(g-h) n=18-27)$. Asterisks indicate when values were significantly different between sites, on the basis of a Mann-Whitney t-test $(\mathrm{P}<0.05)$ for $\mathrm{pH}$ values converted to $\mathrm{H}^{+}$values, or on the basis of an unpaired t-test $(\mathrm{P}<0.05)$ for the remaining variables. 

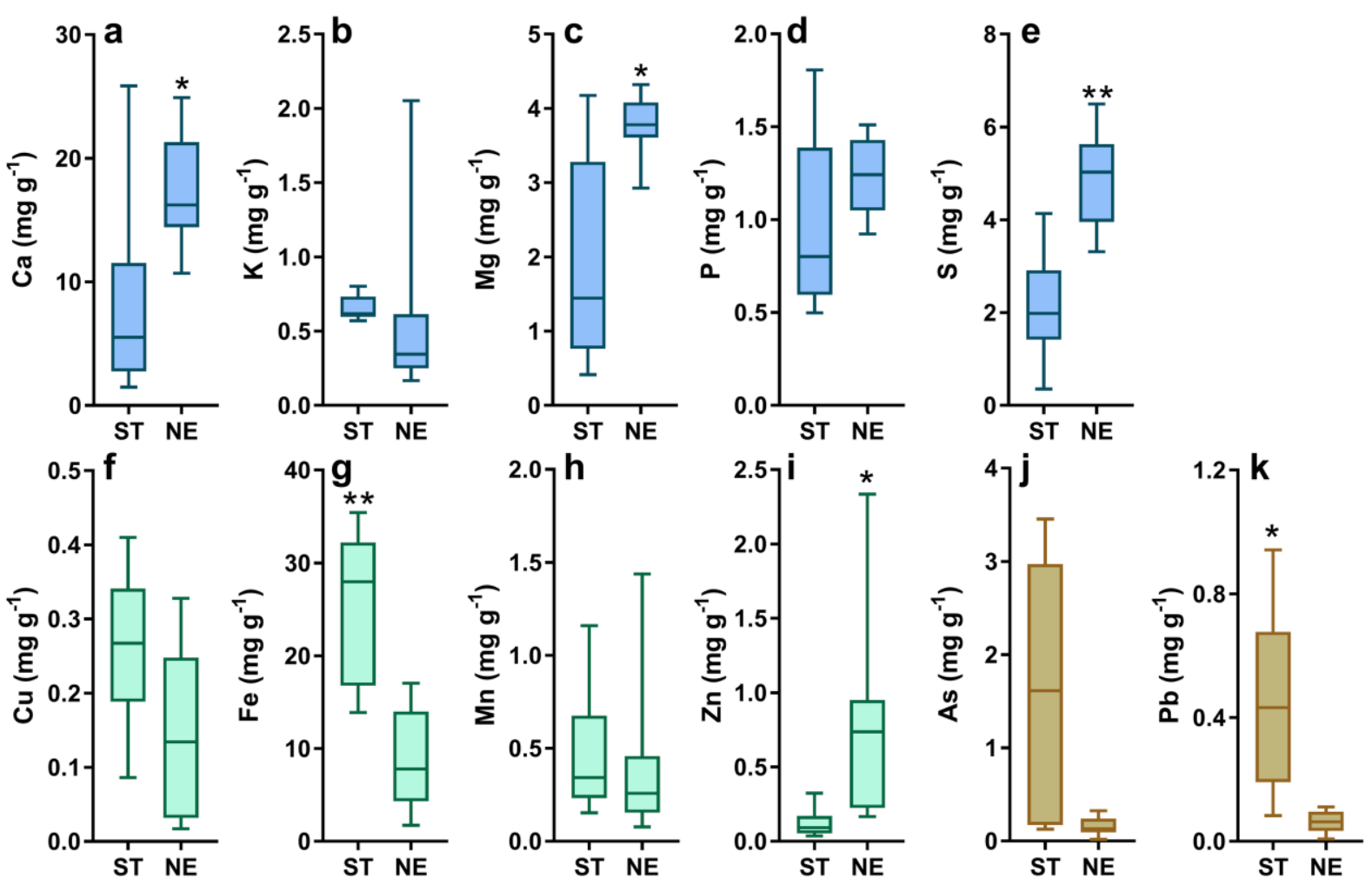

Fig. 3. Soil element concentrations from South Terras (ST) and Needle's Eye (NE). (a - e) essential macro-elements, $(f-i)$ essential micro-nutrients, and $(j-k)$ non-essential elements. Boxes show the $25^{\text {th }}$ and $75^{\text {th }}$ percentiles, the line within the boxes shows the median values, and the whisker bars show minimum and maximum values $(n=18-27)$. Asterisks indicate when values were significantly different between sites, on the basis of an unpaired t-test $(P<$ $0.05)$. 

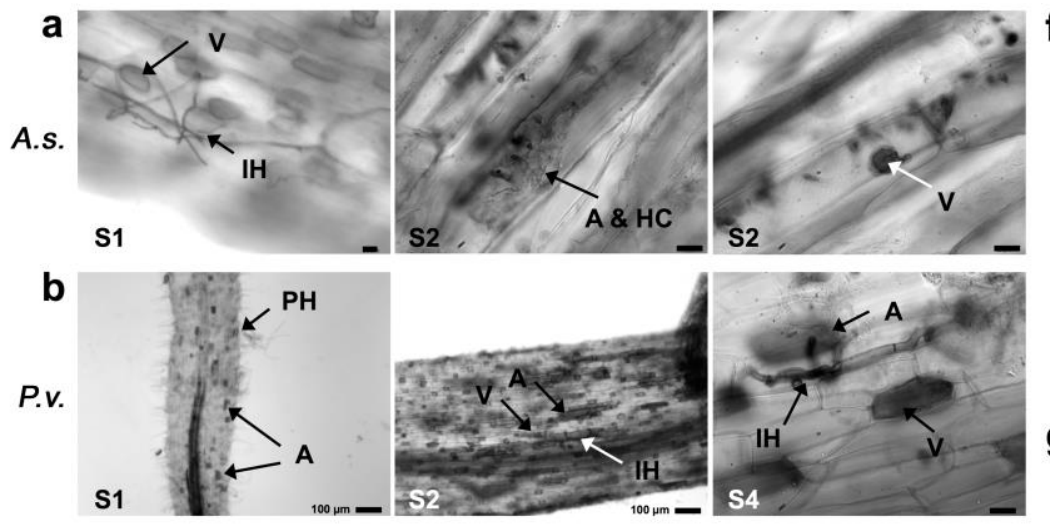

C EH

c.o.

in Supplementary Table S1.


Fig. 4. AM fungal association in plants from South Terras and Needle's Eye. $(a-e)$ Aniline blue stained micrographs of mycorrhizal root samples taken from South Terras plants $A$. scolopendrium L. (A.s.) (a) and P. vulgaris Huds. (P.v.) (b), and Needle's Eye plants $C$. oppositifolium L. (C.o.) (c), I. pseudacorus L. (I.p.) (d) and O. crocata L. (O.c.) (e). Stained AM fungal structures include arbuscles $(A)$, intraradical hyphae $(\mathrm{IH})$, extraradical hyphae $(\mathrm{EH})$, penetrating hyphae $(\mathrm{PH})$, vesicles $(\mathrm{V})$ and hyphal coils $(\mathrm{HC})$. Non-fungal structures including oomycetes $(\mathrm{OM})$ were also seen. Scale bar $=10 \mu \mathrm{m}$ unless indicated. $(\mathrm{f}-\mathrm{h})$ Quantification of AM fungal colonisation in root tissue of plant specimens collected from South Terras and Needle's Eye on the basis of mean \% intraradical hyphae (f), \% arbuscules $(g)$, and \% vesicles $(h)$. Triplicate replicates $(n=3)$ from each sample per plant species were analysed. The total number of root intersections and replications are detailed 




Fig. 5. Percentage abundance of AM fungal sequences within different taxonomic genera from root samples collected from South Terras and Needle's Eye. Individual segments

A $\square$ Glomeromycetes; Archaeosporales; Archaeosporaceae; unidentified

B $\square$ Glomeromycetes; Diversisporales; Acaulosporaceae; Acaulospora

C $\square$ Glomeromycetes; Diversisporales; Diversisporaceae; Diversispora

D $\square$ Glomeromycetes; Diversisporales; Diversisporaceae; unidentified

E $\square$ Glomeromycetes; Glomerales; Claroideoglomeraceae; Claroideoglomus

F $\square$ Glomeromycetes; Glomerales; Glomeraceae; Glomus

G $\square$ Glomeromycetes; Glomerales; Glomeraceae; Rhizophagus

H $\square$ Glomeromycetes; Glomerales; Glomeraceae; unidentified

I 口Glomeromycetes; Glomerales; unidentified; unidentified

J 口Glomeromycetes; Paraglomerales; Paraglomeraceae; Paraglomus

K $\square$ unidentified Glomeromycota representing more than $2 \%$ of the total are labelled with a letter to aid identification. The total number of sequences belonging to Glomeromycota for each plant species is indicated. Triplicate root replicates $(n=3)$ from each sample per plant species were analysed. 

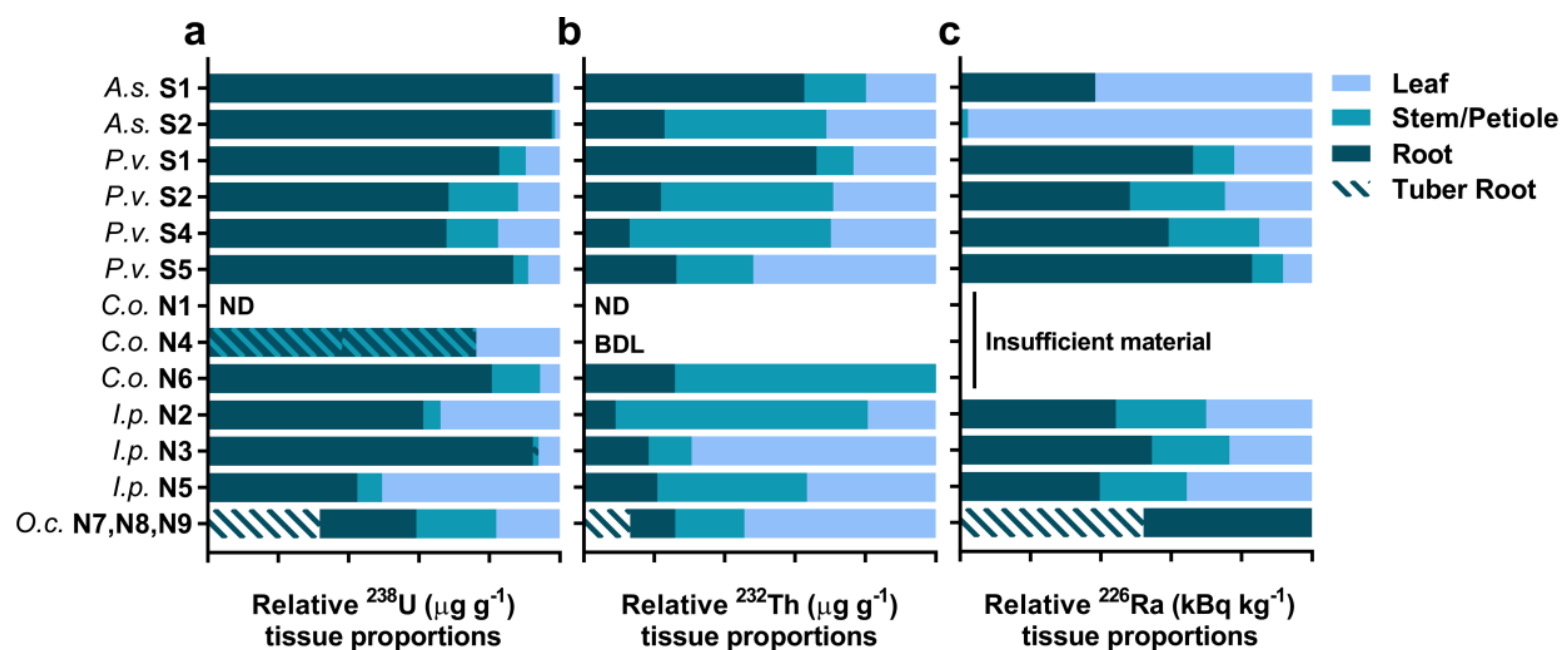

Fig. 6. Relative plant tissue proportions of ${ }^{238} \mathrm{U},{ }^{232} \mathrm{Th}$ and ${ }^{226} \mathrm{Ra}$ from plant samples collected from South Terras and Needle's Eye. C. oppositifolium stem/petiole and root material from site $\mathrm{N} 4$ was combined for ${ }^{238} \mathrm{U}$ analysis (striped bar). O. crocata tissue from sites N7, N8 and N9 was combined, with root tissue divided into fibrous root and tuber root (T) material. ND, not determined; BDL, below detectable limits. Samples were analysed from South Terras sites S1, S2, S4 and S5, and Needle's Eye sites N1 - N9. A.s., A. scolopendrium L.; P.v., P. vulgaris Huds.; C.o., C. oppositifolium L.; I.p., I. pseudacorus L.; O.C., O. crocata L. Each bar represents an individual plant sample. Data was derived from ICP-MS $\left({ }^{238} \mathrm{U}\right.$ and $\left.{ }^{232} \mathrm{Th}\right)$ and $\mathrm{Y}$-spectroscopy $\left({ }^{226} \mathrm{Ra}\right)$ analysis. 



Fig. 7. Transfer factors of ${ }^{238} \mathrm{U},{ }^{232} \mathrm{Th}$ and ${ }^{226} \mathrm{Ra}$ from soil to plant tissues of samples collected from South Terras and Needle's Eye. C. oppositifolium stem/petiole and root material from site $\mathrm{N} 4$ was combined for ${ }^{238} \mathrm{U}$ analysis (striped bar). O. crocata tissue from sites $\mathrm{N} 7, \mathrm{~N} 8$ and N9 was combined, with root tissue divided into fibrous root and tuber root (T) material. ND, not determined; BDL, below detectable limits. Samples were analysed from South Terras sites S1, S2, S4 and S5, and Needle's Eye sites N1 - N9. A.S., A. scolopendrium L.; P.v., P. vulgaris Huds.; C.o., C. oppositifolium L.; I.p., I. pseudacorus L.; O.c., O. crocata L. Each bar represents an individual plant sample. Data was derived from ICP-MS $\left({ }^{238} \mathrm{U}\right.$ and $\left.{ }^{232} \mathrm{Th}\right)$ and $\mathrm{Y}$-spectroscopy $\left({ }^{226} \mathrm{Ra}\right)$ analysis. 

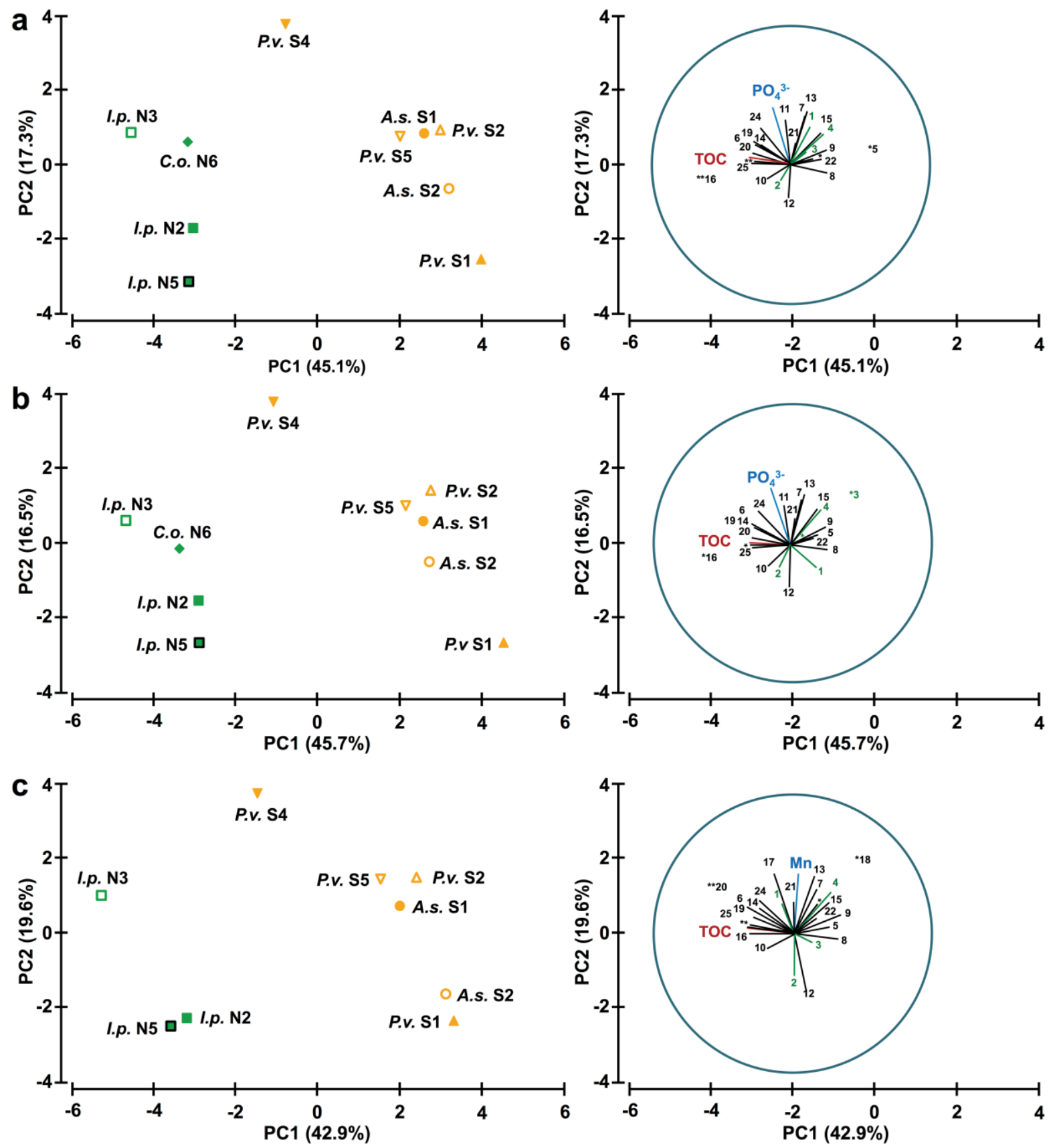

Fig. 8. Identification of variables that discriminate plant samples on the basis of root concentrations of ${ }^{238} \mathrm{U},{ }^{232} \mathrm{Th}$ and ${ }^{226} \mathrm{Ra}$. (a - c) PCA plots for root ${ }^{238} \mathrm{U}(\mathrm{a})$, root ${ }^{232} \mathrm{Th}(\mathrm{b})$ and root ${ }^{226} \mathrm{Ra}(\mathrm{c})$. Factors with the largest loading in PC1 and PC2 are highlighted in red and blue, respectively. Eigenvalue tables for each PCA are shown in Table S5. A.s., A. scolopendrium L.; P.v., P. vulgaris Huds.; C.o., C. oppositifolium L.; I.p., I. pseudacorus L. The plant variables are: 1 , root $\mathrm{U} / \mathrm{Th} / \mathrm{Ra} ; 2$, \% arbuscules; 3 , \% hyphae; 4 , \% vesicles; and the soil variables are: $5, \mathrm{As} ; 6, \mathrm{Ca} ; 7, \mathrm{Cu} ; 8, \mathrm{Fe} ; 9, \mathrm{~K} ; 10, \mathrm{Mg} ; 11, \mathrm{Mn} ; 12, \mathrm{NH}_{4}^{+} ; 13, \mathrm{NO}_{3}^{-} ; 14$, $\mathrm{P} ; 15, \mathrm{~Pb} ; 16, \mathrm{pH} ; 17, \mathrm{PO}_{4}{ }^{3-} ; 18, \mathrm{Ra} ; 19, \mathrm{~S} ; 20, \mathrm{SO}_{4}{ }^{2} ; 21, \mathrm{TIC} ; 22, \mathrm{Th} ; 23, \mathrm{TOC} ; 24, \mathrm{U} ; 25$, $\mathrm{Zn}$. 



Mg SOIL

958 Fig. 9. Linear regression analyses for selected soil abiotic factors in relation to ${ }^{238} \mathrm{U},{ }^{232} \mathrm{Th}$ or ${ }^{226} \mathrm{Ra}$ root concentrations. (a - c) Correlation plots for ${ }^{238} \mathrm{U}(\mathrm{a}),{ }^{232} \mathrm{Th}(\mathrm{b})$ and ${ }^{226} \mathrm{Ra}$ (c). All element concentration data were $\ln (0.1+\mathrm{V})$ transformed for ${ }^{238} \mathrm{U}$ and ${ }^{226} \mathrm{Ra}$ data, but was square root transformed for ${ }^{232}$ Th data, with South Terras and Needle's Eye data points presented as open and closed circles, respectively. 



$\%$ VESICLES

$\%$ HYPHAE

Fig. 10. Linear regression analyses for $A M$ fungal colonisation in relation to ${ }^{238} \mathrm{U},{ }^{232} \mathrm{Th}$ or ${ }^{226} \mathrm{Ra}$ root concentrations. (a - c) Correlation plots for ${ }^{238} \mathrm{U}(\mathrm{a}),{ }^{232} \mathrm{Th}(\mathrm{b})$ and ${ }^{226} \mathrm{Ra}$ (c). All element concentration data were $\ln (0.1+\mathrm{V})$ transformed for ${ }^{238} \mathrm{U}$ and ${ }^{226} \mathrm{Ra}$ data, but was square root transformed for ${ }^{232}$ Th data, with South Terras and Needle's Eye data points presented as open and closed circles, respectively. 